\title{
DIGITAL SIMULATION MODEL OF THE \\ WENONAH-MOUNT LAUREL AQUIFER IN \\ THE COASTAL PLAIN OF NEW JERSEY
}

\section{U.S. GEOLOGICAL SURVEY}

Open-File Report 75-672

Prepared in cooperation with New Jersey Department of

Environmental Protection, Division of Water Resources 


\section{UNITED STATES \\ DEPARTMENT OF THE INTERIOR \\ GEOLOGICAL SURVEY}

DIGITAL-SIMULATION MODEL OF THE

WENONAH-MOUNT LAUREL AQUIFER IN

THE COASTAL PLAIN OF NEW JERSEY

By Bronius Nemickas

Open-File Report 75-672

Prepared in cooperation with New Jersey Department of

Environmental Protection, Division of Water Resources

Trenton. New Jersey

January 1976 
UNITED STATES DEPARTMENT OF THE INTERIOR

Thomas S. Kleppe, Secretary

GEOLOGICAL SURVEY

Vincent E. McKelvey, Director

For additional information write to:

U.S. Geological Survey

Rm. 420 Federal Bldg.

P.O. Box 1238

Trenton, N.J. 08607 


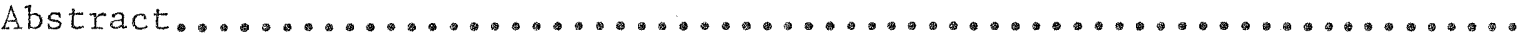

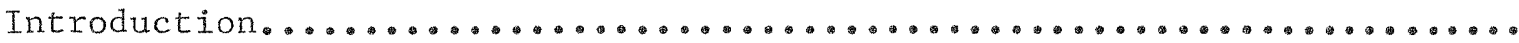

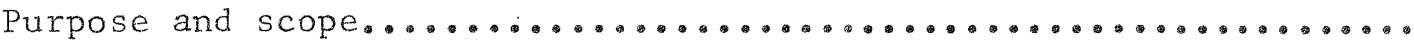

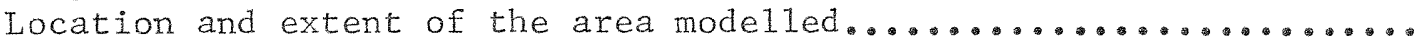

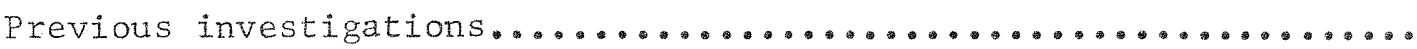

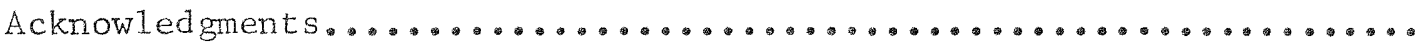

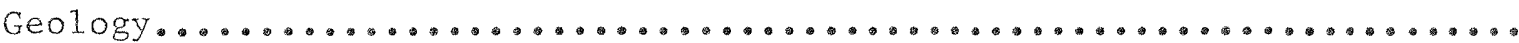

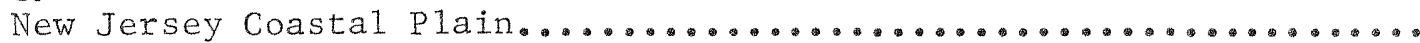

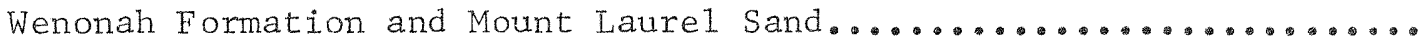

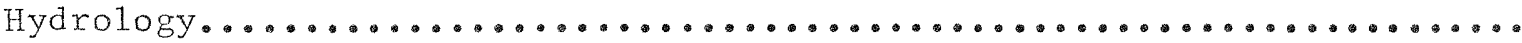

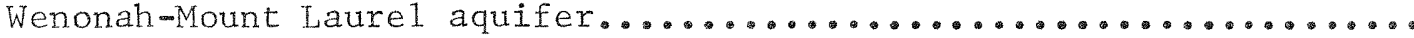

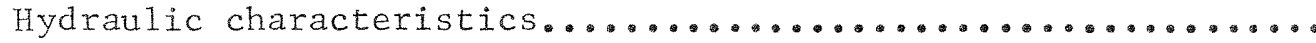

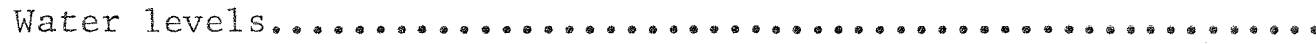

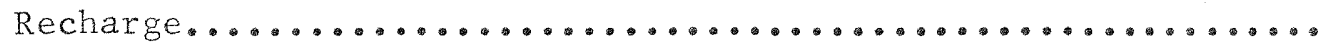

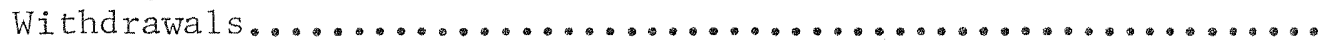

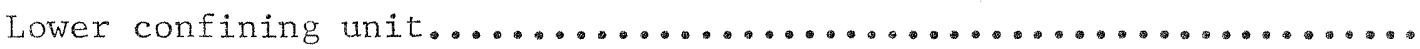

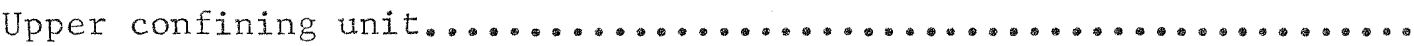

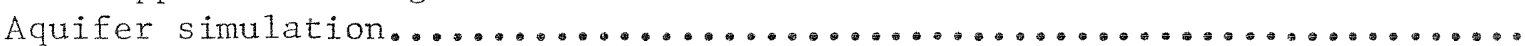

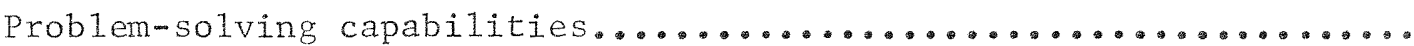

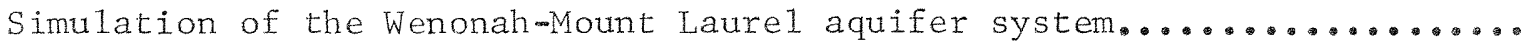

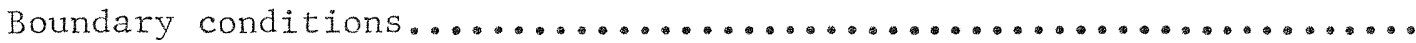

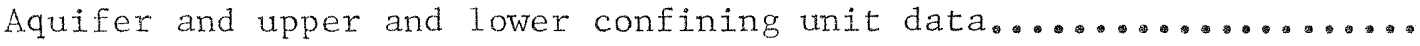

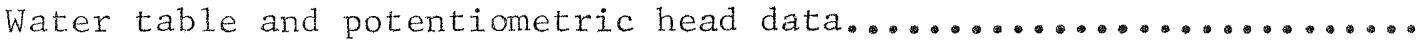

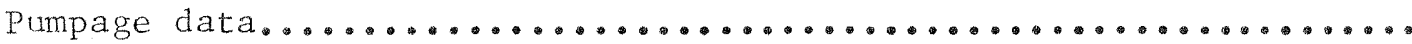

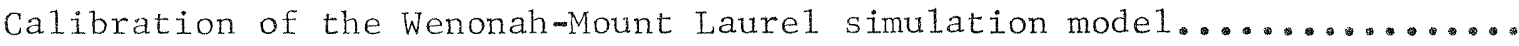

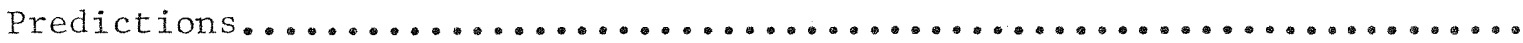

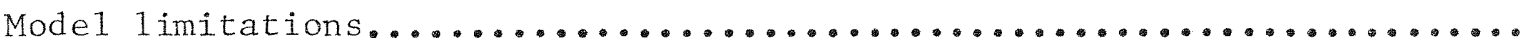

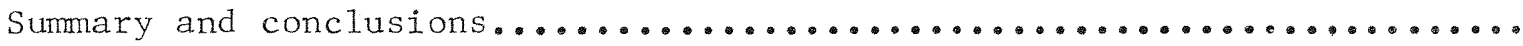

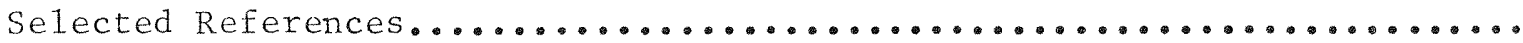

\section{ILLUSTRATIONS}

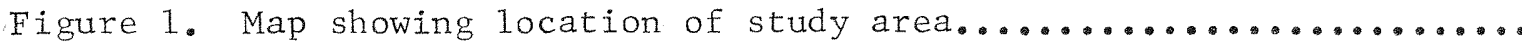

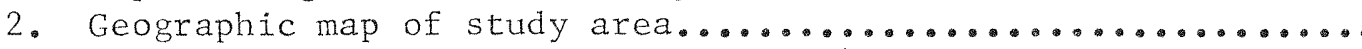

3. Structure contour map of the top of the Mount Laurel Sand in

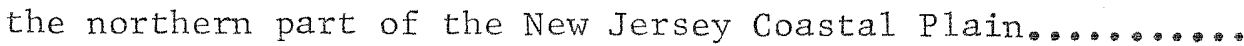

4. Structure contour map of the base of the Wenonah Formation in the northern part of the New Jersey Coastal Plain.......... 10

5. Thickness of the Wenonah Formation and Mount Laurel Sand......

6. Sand lithofacies thickness of the Wenonah Formation and Mount

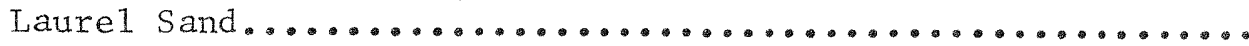

7. Section $A-A^{\prime}$ showing the relationship of the Wenonah Formation, Mount Laure1 Sand, Wenonah-Mount Laurel aquifer,

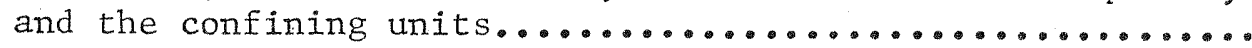


Figure 8. Potentiometric surface of the Wenonah-Mount Laurel aquifer,

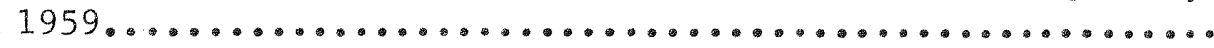

9. Potentiometric surface of the Wenonah-Mount Laure1 aquifer,

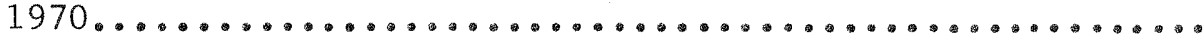

10. Water-leve1 decline in the Wenonah-Mount Laurel aquifer,

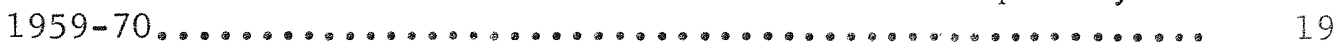

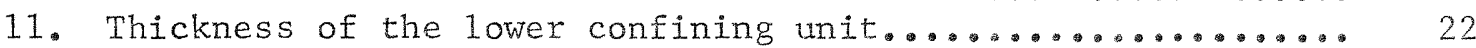

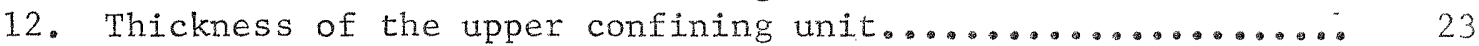

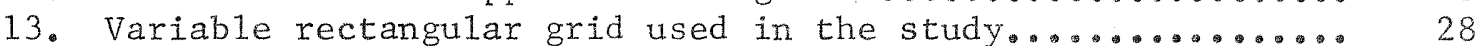

14. Transmissivity map of the Wenonah-Mount Laurel aquifer...... 29

15. Storage coefficient map of the Wenonah-Mount Laurel aquifer, 30

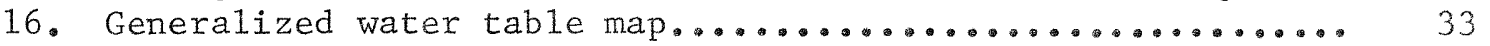

17. Potentiometric map of the Englishtown aquifer, 1959........ 34

18. Decline in potentiometric surface in the Englishtown aquifer,

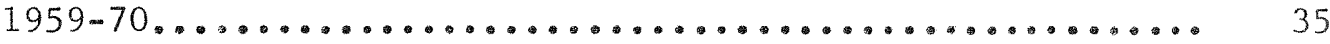

19. Potentiometric decline map in the Wenonah-Mount Laure1 aquifer 1959-70 as computed by the simulation mode1...... 36

20. Predicted potentiometric decline in the Wenonah-Mount Laurel aquifer by the simulation model for $1959-78 \ldots \ldots \ldots \ldots \ldots$

TABLES

Table 1. Stratigraphic units in the northern Coastal Plain of New

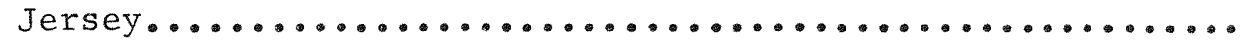

2. Public-supply withdrawals from the Wenonah-Mount Laure1

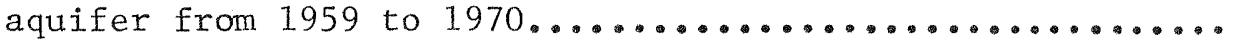

3. Hydraulic parameters used in the Wenonah-Mount Laurel aquifer-

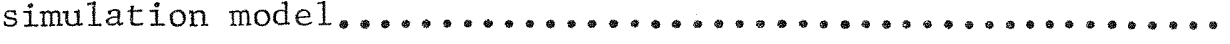


Factors for converting English units to metric units are shown to four significant figures. However, in the text the metric equivalents are shown only to the number of significant figures consistent with the values for the English units.

\section{English}

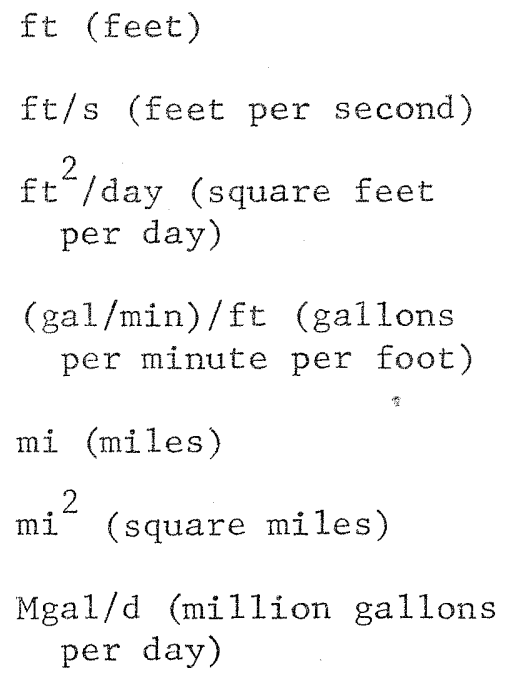

\section{Multiply by}

$$
0.3048
$$

0.3048

0.0929

$1.242 \times 10^{-2}$

1.609

2.590

43.81

\section{Metric}

$\mathrm{m}$ (metres)

$\mathrm{m} / \mathrm{s}$ (metres per second)

$\mathrm{m}^{2} /$ day (square metres per day)

$\left(\mathrm{m}^{3} / \mathrm{min}\right) / \mathrm{m}$ (cubic metres per minute per metre)

$\mathrm{km}$ (kilometres)

$\mathrm{km}^{2}$ (square kilometres)

$\mathrm{dm}^{3} / \mathrm{s}$ (cubic decimetres per second) 
DIGITAL-SIMULATION MODEL OF THE WENONAH-MOUNT LAUREL AQUTFER IN THE COASTAL PLAIN OF NEW JERSEY

By Bronius Nemickas

\section{ABSTRACT}

A digital computer-simulation model of the Wenonah-Mount Laure 1 aquifer is used to evaluate the aquifer's capabilities of meeting the projected future demands and to study the cause of the rapidly declining water levels. The modelled area includes 1,500 square miles $(3,885$ square kilometres) of the New Jersey Coastal Plain and includes all the important centers of pumping in Monmouth, Burlington, and Ocean Counties from the Wenonah-Mount Laurel aquifer.

The Wenonah Formation and Mount Laurel Sand of Late Cretaceous age are exposed in the western part of the New Jersey Coastal Plain along a belt trending northeast-southwest from Raritan Bay to Delaware Bay. The formations typically consist of poorly sorted silty to fine quartz sand, the Wenonah Formation, and a coarse clastic quartz sand unit, the Mount Laurel Sand. The Wenonah-Mount Laurel aquifer is composed of the sandy part of the geologic units.

Transmissivity of the aquifer ranges from 360 square feet per day (33.4 square metres per day) to 1,430 square feet per day (132.8 square metres per day); the estimated hydraulic conductivity ranges from about $1.5 \times 10^{-4}$ feet per second ( $4.6 \times 10^{-5}$ metres per second) to $2.2 \times 10^{-4}$ feet per second $\left(6.7 \times 10^{-5}\right.$ metres per second); and the storage coefficient varies from about $1.5 \times 10^{-5}$ to $3.5 \times 10^{-4}$.

The annual average rate of withdrawal from the Wenonah-Mount Laurel aquifer in Monmouth, Burlington, and Ocean Counties increased from about 1 million gallons per day ( 44 cubic decimetres per second) in 1959 to slightly more than 2 million gallons per day ( 88 cubic decimetres per second) in 1970. Near the pumping centers in Monmouth County, the water level declined as much as 100 feet (30.5 metres) between 1959 and 1970. In the subjacent Englishtown aquifer underlying the lower confining unit (Marshalltown Formation), the annual average rate of withdrawal in all of Monmouth and Ocean Counties increased from 5.5 million gallons per day (241 cubic decimetres per second) in 1959 to 9.5 million gallons per day (416 cubic decimetres per second) in 1970. Water-level declines for the same period are as much as 140 feet ( 42.7 metres) near centers of pumping.

The digital-simulation model was calibrated by matching computed declines in the Wenonah-Mount Laurel aquifer with historic water-level declines over the 12-year period, 1959-70. The results of the modeling show that recharge to the aquifer occurs as leakage from the upper confining unit owing to withdrawals from the aquifer. Of equal significance is the effect of water-level declines in the Englishtown aquifer, which generate leakage from the Wenonah-Mount Laurel aquifer through the lower confining 
unit, which in turn generates leakage (recharge) to the aquifer from the upper confining unit. The rapid declines of water levels in the WenonahMount Laurel aquifer in the northern part of the New Jersey Coastal Plain, hence, are caused directly by the withdrawals from the Wenonah-Mount Laure1 aquifer and indirectly by withdrawals from the underlying Englishtown aquifer.

\section{INTRODUCTION}

\section{Purpose and Scope}

The U.S. Geological Survey, in cooperation with the Division of Water Resources of the New Jersey Department of Environmental Protection, is conducting a program of geohydrologic studies of aquifer systems in the New Jersey Coastal Plain. These studies utilize analytical hydrologic techniques and digital computer-simulation modelling to identify and use the data that are essential to a quantitative study of the hydraulics of the aquifer. A digital computer-simulation model provides a tool for the investigator to test and evaluate different concepts of the functioning of the ground-water system.

The ground-water investigation of the Wenonah Formation and Mount Laure1 Sand was started in August 1970. The purpose of the investigation is to present the geohydrology and the geohydrologic parameters needed for a quantitative analysis of the aquifer and to present a calibrated digital model of the Wenonah-Mount Laure1 aquifer. The geologic framework of the Wenonah Formation and Mount Laure1 Sand, lithologic character and geometry of the Wenonah-Mount Laurel aquifer, and geometry of the overlying and underlying confining units used in the model are described and defined.

The aquifer in the Wenonah Formation and Mount Laurel Sand is a source of ground water in the northern part of the New Jersey Coastal Plain. Total ground-water withdrawal from this aquifer for public supply in Monmouth, Burlington, and Ocean Counties increased from about $0.96 \mathrm{Mga} / \mathrm{d}$ (million gallons per day) [42 cubic decimetres per second $\left.\left(\mathrm{dm}^{3} / \mathrm{s}\right)\right]$ in 1959 to about $2.2 \mathrm{Mgal} / \mathrm{d}(96 \mathrm{dm} 3 / \mathrm{s})$ in 1970 . Water levels in the aquifer have been declining at a rate of 3 to 8 feet ( $\mathrm{ft}$ ) per year $[0.9$ to 2.4 metres (m) per year] in Monmouth and Ocean Counties near the Atlantic coast, since 1959. This water-level decline is caused directly by withdrawals from the Wenonah-Mount Laurel aquifer and, as shown by this study, indirectly by withdrawals from the underlying Englishtown aquifer. Water levels in the Englishtown aquifer have declined in southeastern Monmouth and northern Ocean Counties at the rate of 8 to $12 \mathrm{ft}$ per year (2.4 to $3.7 \mathrm{~m}$ per year) since 1959 (Nichols, written commun., 1974). 
The model in its present development stage can be used, with the limiting assumptions, by ground-water planners in providing estimates of the effects of various proposed withdrawal schemes from the Wenonah-Mount Laurel aquifer.

Location and Extent of the Area Modelled

The geohydrologic investigation of the Wenonah-Mount Laurel aquifer covers an area of about $1,500 \mathrm{sq} \mathrm{mi}$ (square miles) $\left[3,885 \mathrm{~km}^{2}\right.$ (square kilometres)] of the Coastal Plain of New Jersey (fig, 1). The modelled area of $1,500 \mathrm{sq} \mathrm{mi}\left(3,885 \mathrm{~km}^{2}\right)$ is bounded on the north by Raritan Bay, on the northwest by the feather edge of the Wenonah Formation and Mount Laurel Sand, and on the east by the Atlantic Ocean. The southern boundary is in Ocean, Burlington, and Camden Counties (fig. 2). The area modelled includes the major areas of ground-water use and development in the WenonahMount Laurel aquifer in Monmouth, Burlington, and Ocean Counties.

\section{Previous Investigations}

The geology of the Coastal Plain of New Jersey and of the Wenonah Formation and Mount Laurel Sand has been discussed by a number of authors. Some of the more recent investigations are by Owens and others (1968, 1970), Owens and Soh1 (1969), Minard (1964, 1965), Minard and others (1969), and Owens and Minard (1966).

The regional geohydrology of the Coastal Plain of New Jersey and of the Wenonah Formation and Mount Laurel Sand was discussed by Barksdale and others (1958) and Parker and others (1964). Well records, wel1 logs, chemical analyses, and brief descriptions of the hydrology, water quality, and geology of the Wenonah Formation and Mount Laurel Sand are given in the following county reports: Rush (1968) on Burlington County; Anderson and Appe1 (1969) on Ocean County; Jablonski (1968) on Monmouth County; Farlekas, Nemickas, and Gi11 (1973) on Camden County; Hardt (1963) and Hardt and Hilton (1969) on Gloucester County; Rosenau and others (1968) on Salem County; and Rooney (1971) and Nemickas (1974) on Cumberland County.

\section{Acknowledgments}

The investigation was made by the U. S. Geological Survey in cooperation with the Division of Water Resources of the New Jersey Department of Environmental Protection. Dr. B. L. Smith of Rutgers University assisted the author greatly with informal discussions. Michael G. McDonald of the U. S. Geological Survey provided invaluable assistance in computer programming.

\section{GEOLOGY}

\section{New Jersey Coastal Plain}

The Coastal Plain of New Jersey is underlain by unconsolidated and partly consolidated marine, marginal marine, and nonmarine deposits of gravel, 


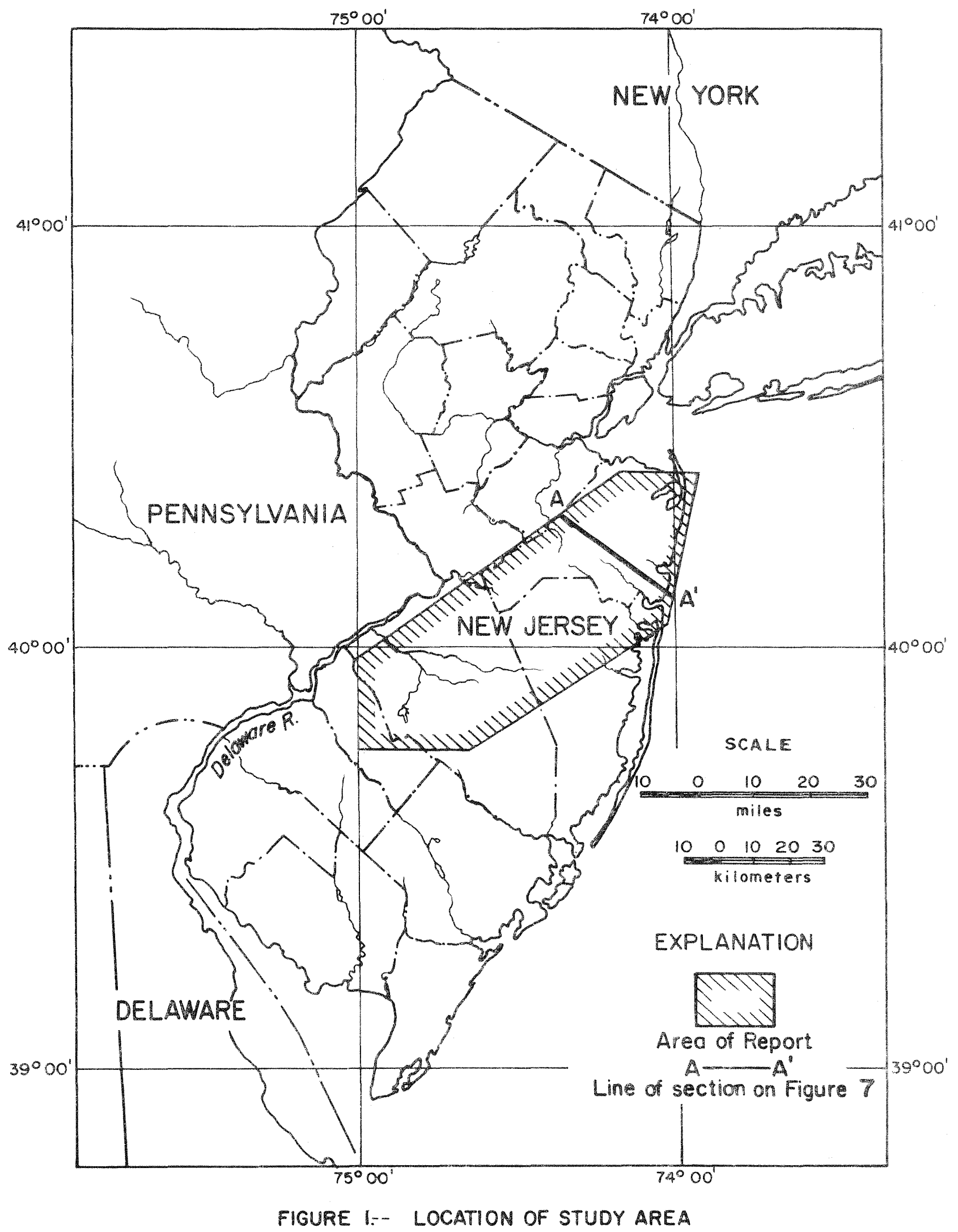




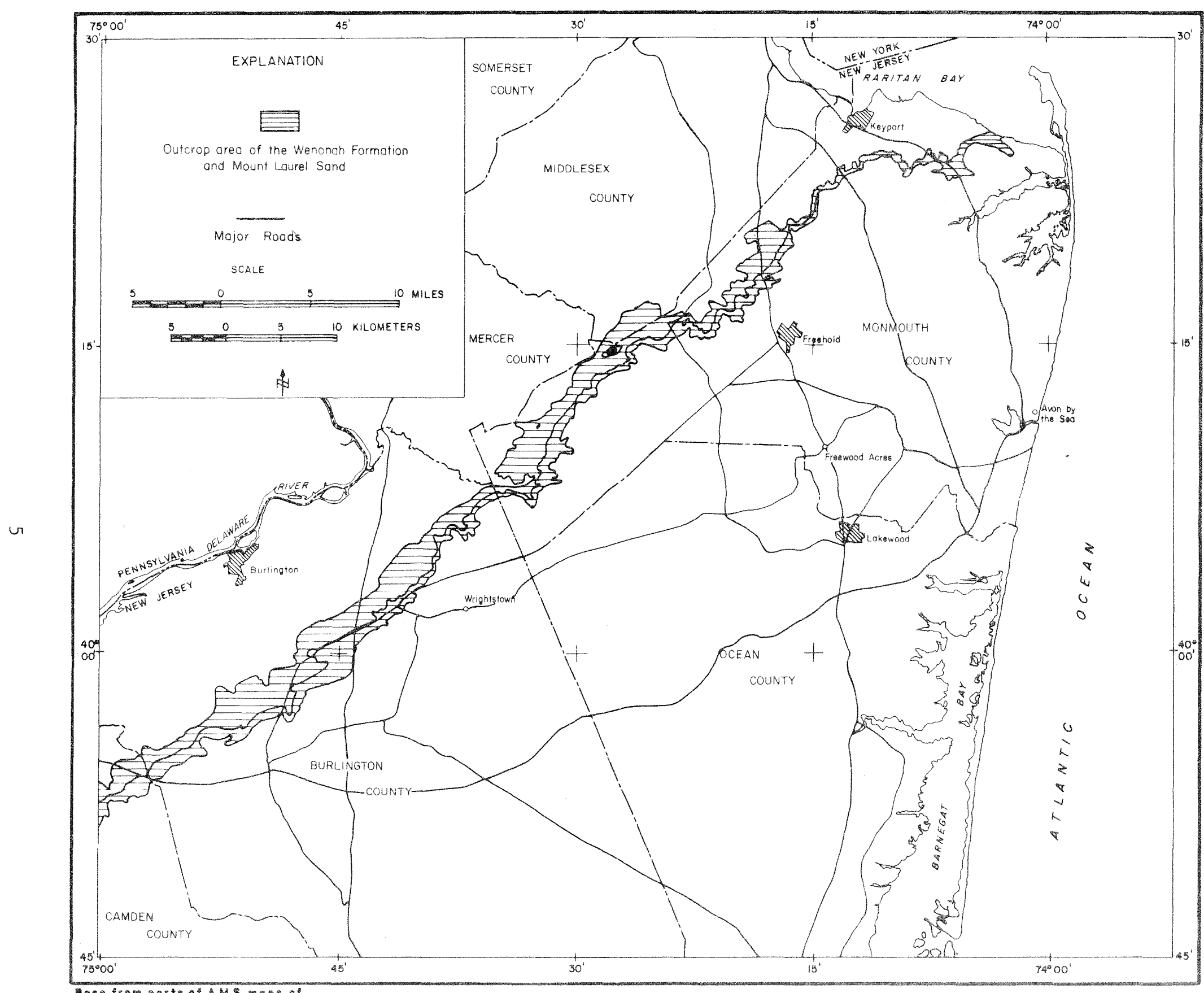

Waze from parts of A M $S$ mape of 
sand, silt, and clay. The sediments range in age from Cretaceous to Holocene and lie unconformably on the pre-cretaceous basement. The altitude of the basement complex ranges from $100 \mathrm{ft}(30.5 \mathrm{~m})$ above sea level in the noxthwestern Coastal Plain to $6,400 \mathrm{ft}(1,950 \mathrm{~m})$ below sea level in the southern tip of Cape May County. The total thickness of the sediments in outcrop range from 500 to $1,000 \mathrm{ft}$ ( 152 to $305 \mathrm{~m}$ ). The sediments thicken downdip, toward the southeast, and attain a maximum thickness of about 6,500 ft $(1,980 \mathrm{~m})$ at the extreme southern. tip of Cape May County (Gil1 and Farlekas, written commun., 1974). The sediments of Cretaceous and Tertiary age dip gently to the southeast with the oldest sediments cropping out at the Delaware River. In general, the older the sediments are, the steeper is the dip. The Quaternary formations (Bridgeton, Pensauken, and Cape May) are not continuous and, where present, are virtually flat-lying beds that overlie the Cretaceous and Tertiary sediments.

Many investigators have discussed the geology of the New Jersey preQuaternary Coastal Plain formations, and the work was recently summarized by Owens and others (1970) and Owens and Soh1 (1969). The differences in sediments between Delaware Bay and Raritan Bay reflect different patterns and environments of sedimentation that existed in the New Jersey Coastal Plain, especially during Late Cretaceous time. Depositional patterns in the Coastal Plain of New Jersey have been largely controlled by two basement tectonic features; a trough centering in the vicinity of Raritan Bay and a northwestsoutheast trending high in southern New Jersey.

The northern Coastal Plain sediments (table 1) can be grouped into two major stratigraphic units. The lower stratigraphic unit, of fluvial-deltaic and marginal-marine origin, ranges in age from Early Cretaceous to Eocene and is marked by an abundance of siderite. The fluvial-deltaic sediments of the Potomac Group and the Raritan and Magothy Formations form the base of this sequence (Gi11 and Farlekas, written commun., 1969). The upper part (Merchantville Formation and younger) of the lower unit, deposited during several transgressive and regressive cycles, becomes progressively more marine indicating deeper water deposits. The upper stratigraphic unit ranges in age from middle Miocene through Pliocene(?) and is characterized by the absence of glauconite and the first appearance of thick marine diatom beds of the Kirkwood Formation (Gi1l and Farlekas, written commun., 1969).

The major fresh-water aquifers in the Coastal. Plain of New Jersey are sands and gravels of Cretaceous and Tertiary age in the Potomac Group, the Raritan and Magothy Formations, the Englishtown Formation, the Wenonah Formation and Mount Laurel Sand, the Kirkwood Formation, and the Cohansey Sand. Minor aquifers are found locally in parts of the Merchantville Formation, Red Bank Sand, Vincentown Formation, and Manasquan Formation. Sand and gravel in the surficial deposits of Quaternary age are commonly hydraulically connected to the adjacent underlying aquifers. 
Table 1.--Stratigraphic units in the northern Coastal Plain of New Jersey-1/

\begin{tabular}{|c|c|c|c|c|}
\hline Erathem & System & Series & Subdivision & Lithology \\
\hline \multirow{10}{*}{ 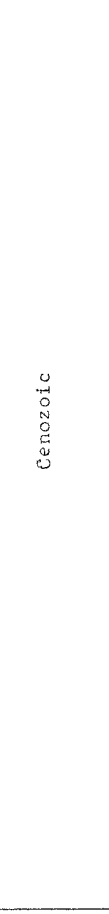 } & \multirow{5}{*}{ 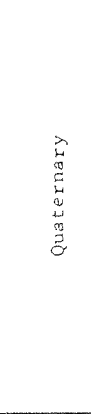 } & \multirow{5}{*}{ 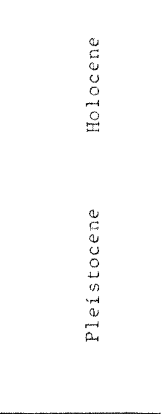 } & Alluvial deposites & $\begin{array}{l}\text { Gray mixture of clay, silt, } \\
\text { organic material, sand, and } \\
\text { gravel. }\end{array}$ \\
\hline & & & Eolian deposits & $\begin{array}{l}\text { Light gray, well sorted quartz } \\
\text { sands. }\end{array}$ \\
\hline & & & $\begin{array}{l}\text { Cape May } \\
\text { Formation }\end{array}$ & $\begin{array}{l}\text { Yellow to brown to gray, medium } \\
\text { to coarse-grained quartzose sand. }\end{array}$ \\
\hline & & & $\begin{array}{l}\text { Pensauken } \\
\text { Formation }\end{array}$ & $\begin{array}{l}\text { Yellow to brown, medium to } \\
\text { coarse-grained quartzose sand. }\end{array}$ \\
\hline & & & $\begin{array}{l}\text { Bridgeton } \\
\text { Formation }\end{array}$ & $\begin{array}{l}\text { White to brown, fine to very } \\
\text { coarse quartzose sand and gravel, } \\
\text { fairly well sorted and subangular. }\end{array}$ \\
\hline & \multirow{5}{*}{ 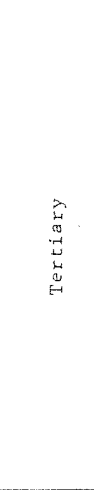 } & 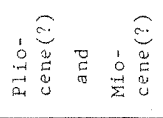 & Cohansey Sand & $\begin{array}{l}\text { Yellowish orange, fine to coarse } \\
\text { quartzose sand and fine gravel, } \\
\text { somewhat micaceous, contains } \\
\text { lenses of silt and clay. }\end{array}$ \\
\hline & & 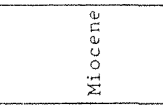 & $\begin{array}{l}\text { Kirkwood } \\
\text { Formation }\end{array}$ & $\begin{array}{l}\text { Light olive gray, glauconitic, } \\
\text { slightly micaceous, very fine } \\
\text { to fine quartzose sand. }\end{array}$ \\
\hline & & 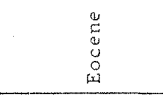 & $\begin{array}{l}\text { Manasquan } \\
\text { Formation }\end{array}$ & $\begin{array}{l}\text { Olive gray, clayey, quartzose, } \\
\text { glauconitic, silty sand. }\end{array}$ \\
\hline & & 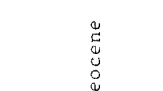 & $\begin{array}{l}\text { Vincentown } \\
\text { Formation }\end{array}$ & $\begin{array}{l}\text { Light brown to gray, very fine, } \\
\text { calcareous, micaceous, sand } \\
\text { and silt. }\end{array}$ \\
\hline & & $\vec{\pi}$ & $\begin{array}{l}\text { Hornerstown } \\
\text { Sand }\end{array}$ & $\begin{array}{l}\text { Dark green glauconitic sand } \\
\text { and clay. }\end{array}$ \\
\hline \multirow{12}{*}{ 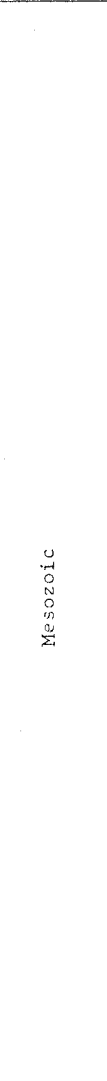 } & \multirow{11}{*}{ 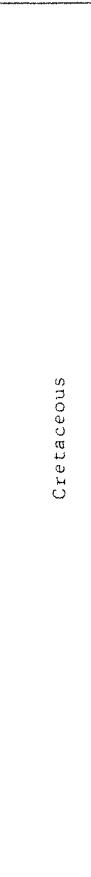 } & \multirow{10}{*}{ 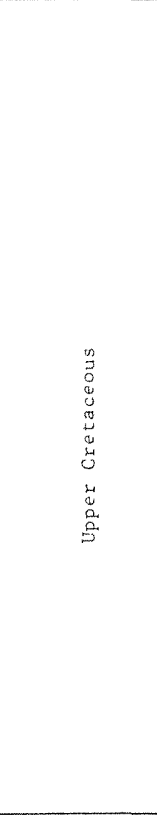 } & Red Bank Sand & $\begin{array}{l}\text { Dark to light gray, fine to coarse- } \\
\text { grained, clayey, lignitic sand. }\end{array}$ \\
\hline & & & $\begin{array}{l}\text { Navesink } \\
\text { Formation }\end{array}$ & $\begin{array}{l}\text { Dark green to black glauconitic } \\
\text { sand and clay. }\end{array}$ \\
\hline & & & $\begin{array}{l}\text { Mount Laurel } \\
\text { Sand }\end{array}$ & $\begin{array}{l}\text { Light gray, fine to coarse- } \\
\text { grained quartz sand. }\end{array}$ \\
\hline & & & $\begin{array}{l}\text { Wenonah } \\
\text { Formation }\end{array}$ & $\begin{array}{l}\text { Dark gray, poorly sorted, very } \\
\text { micaceous, silty, fine quartz sand. }\end{array}$ \\
\hline & & & $\begin{array}{l}\text { Marshall town } \\
\text { Formation }\end{array}$ & $\begin{array}{l}\text { Dark gray, micaceous, silty } \\
\text { glauconite sand. }\end{array}$ \\
\hline & & & $\begin{array}{l}\text { Englishtown } \\
\text { Formation }\end{array}$ & $\begin{array}{l}\text { Massive dark-colored silty } \\
\text { sand. }\end{array}$ \\
\hline & & & Woodbury Clay & $\begin{array}{l}\text { Grayish-black massive micaceous } \\
\text { clayey silt. }\end{array}$ \\
\hline & & & $\begin{array}{l}\text { Merchantuilie } \\
\text { Formation }\end{array}$ & $\begin{array}{l}\text { Dark gray to grayish-black } \\
\text { micaceous clay to clayey silt with } \\
\text { beds and lenses of glauconite sand. }\end{array}$ \\
\hline & & & $\begin{array}{l}\text { Magothy } \\
\text { Formation }\end{array}$ & \multirow{3}{*}{$\begin{array}{l}\text { Alternating clays, silts, sands, } \\
\text { and gravel. }\end{array}$} \\
\hline & & & $\begin{array}{l}\text { Raritan } \\
\text { Formation }\end{array}$ & \\
\hline & & $\begin{array}{c}\text { Lower } \\
\text { Cretaceous }\end{array}$ & Potomac Group & \\
\hline & 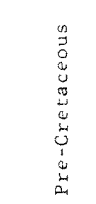 & \multicolumn{2}{|c|}{$\begin{array}{l}\text { Pre-Cretaceous consolidated rocks } \\
\text { and Wissahickon Fornation } \\
\text { (Precambrian to Lower Ordovician). }\end{array}$} & Schist and gneiss. \\
\hline
\end{tabular}


The Wenonah Fomation and the overlying Mount Laurel Sand, both Late Cretaceous in age, crop out in a northeast-southwest trending belt in the New Jersey Coastal Plain. The Wenonah Formation is a dark-gray, poorly sorted, very micaceous, silty, fine quartz sand, Glauconite is abundant in the lower part of the Wenonah Formation but rapidly diminishes in the upper part of the Wenonah Formation (Owens and Soh1, 1969). The contacts of the Wenonah Fomation with the underlying Marshalitown Formation and the overlying Mount Laurel Sand are gradational. The change from the Wenonah Fomation to the Mount Laurel Sand is generally marked by an increase in average grain size, a decrease in mica, and a change in color from dark gray to lighter gray (Owens and Soh1, 1969), Although the Wenonah Fomation and the Mount Laurel Sand are distinct lithologic units, they are hydraulically connected and together form the Wenonah-Mount Laurel aquifer. Whe Mount Laurel Sand, a coarser sand unit than the Wenonah Fomation, is the major component of the aquifer.

The top of the Mount Laurel Sand in the New Jersey Coastal Plain (fig. 3) strikes in a northeast-southwest direction and dips toward the southeast at approximately $30-45$ ft per mi $[5.7$ to $8.5 \mathrm{~m} / \mathrm{km}$ (metres per kilometre)]. The configuration of the base of the Wenonah Formation is show in figure 4.

The combined thickness of the Wenonah Fomation and Mount Laurel Sand in outcrop is as much as $100 \mathrm{ft}(30.5 \mathrm{~m})$. In the subsurface the Wenonah Formation and Mount Laurel Sand range in thickness from $40 \mathrm{ft}$ to slightly more than $200 \mathrm{ft}(12.2$ to $61 \mathrm{~m})$. The thickness map of the Wenonah FormationMount Laurel Sand ( $\mathrm{fig}$. 5) shows that the unit thickens downdip. Interpretation of geophysical logs suggests that the Wenonah Formation and Mount Laurel Sand is manly a sand unit although the lower 30 percent of the unit consists of silt. The sand unit, ranging in thickness from 30 to $100 \mathrm{ft}$ $(9.1$ to $30.5 \mathrm{~m})$, makes up the aquifer in the Wenonah Formation and Mount Laurel Sand. A 1ithologic map of the sand facies is shown in figure 6 . Figure 7 is a cross-section showing the relationship of the Wenonah Formation and Mount Laurel. Sand and the sand facies within the Wenonah Formation and Mount Laurel Sand. This sand facies, which includes most of the Mount Laurel Sand and part of the Wenonah Formation, is the aquifer that was modelled during this investigation. The geologic section ( $f i g, 7$ ) also shows the confining units above and below the aquifer of the Wenonah Formation and Mount Laurel Sand.

\section{HYDROLOGY}

The Wenonah-Mount Laurel aquifer is utilized as a source of water throughout the study area of about $1,500 \mathrm{sq} \mathrm{mi}\left(3,885 \mathrm{~km}^{2}\right)$ of the New Jersey Coastal Plain (fig. 1). Most of the wells in the New Jersey Coastal Plain tapping the aquifer are located in a northeast-southwest trending belt that lies within $20 \mathrm{mi}(32.2 \mathrm{~km})$ of the outcrop. Total ground-water withdrawals for industrial and public supply in Monmouth. Burlington, and Ocean Counties increased from $0.96 \mathrm{Mgal} / \mathrm{d}\left(42 \mathrm{dm}^{3} / \mathrm{s}\right)$ in 1959 to $2.2 \mathrm{Mgal} / \mathrm{d}\left(96 \mathrm{dm}^{3} / \mathrm{s}\right)$ in 1970 . 


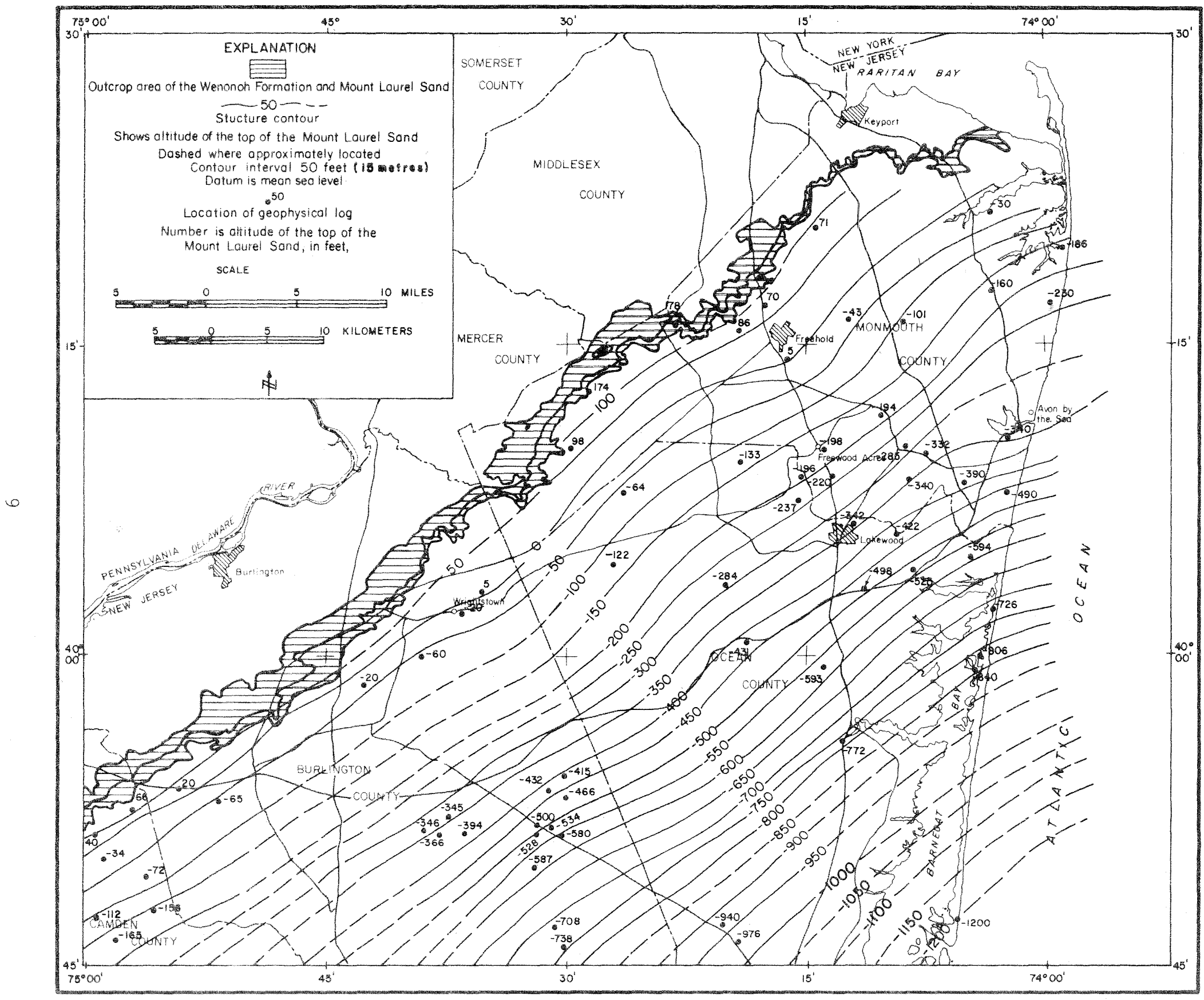

FIGURE 3--STRUCTURE CONTOUR MAP OF THE TOF OF THE MOUNT LAUREL SAND IN NORTHERN PART OF THE NEW JERSEY COASTAL PLAIN 


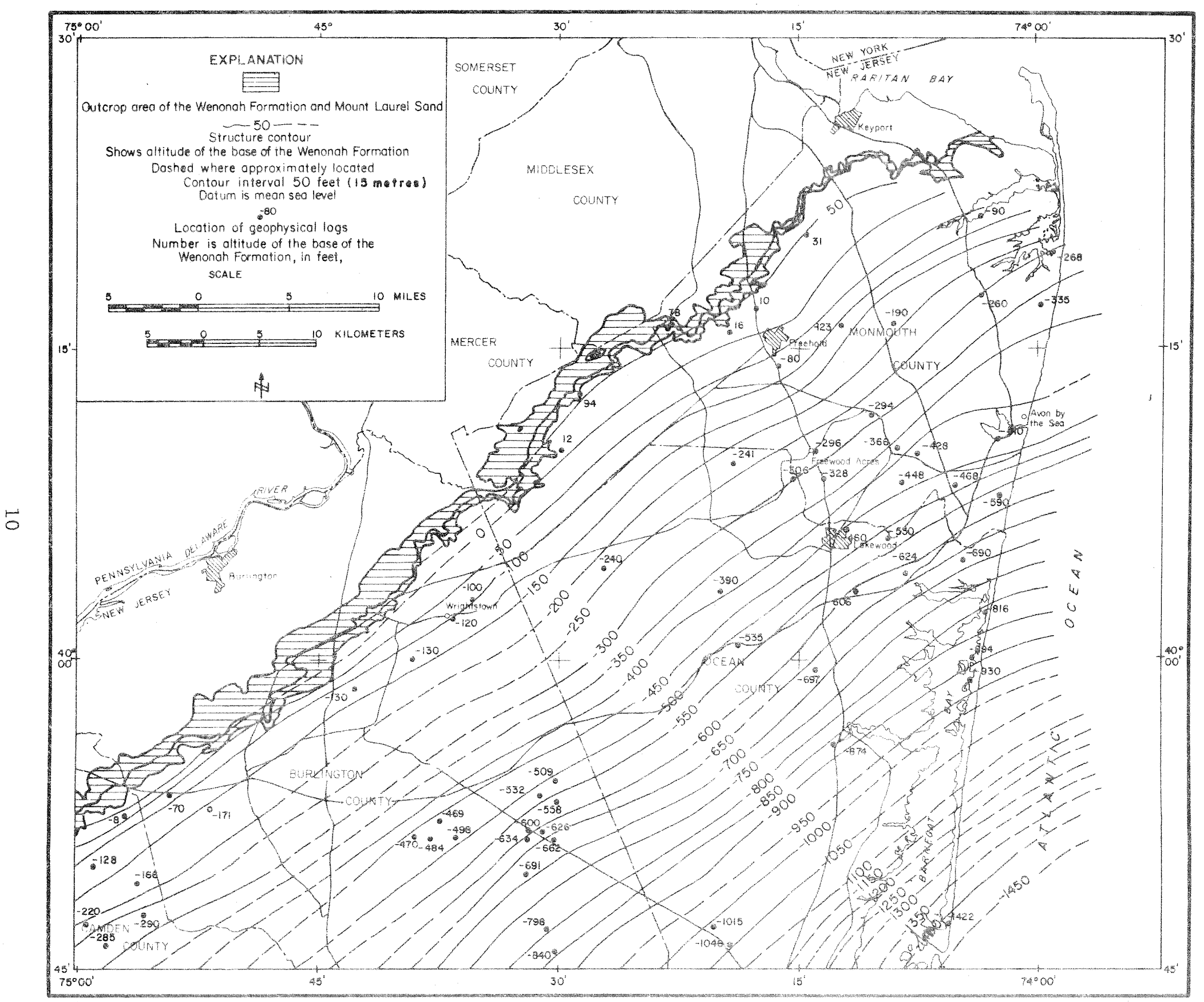

FIGURE 4:- STRUCTURE CONTOUR MAP OF THE BASE OF THE WENONAH FORMATION IN THE NORTHERN PART OF THE NEW JERSEY COASTAL FLAIN 


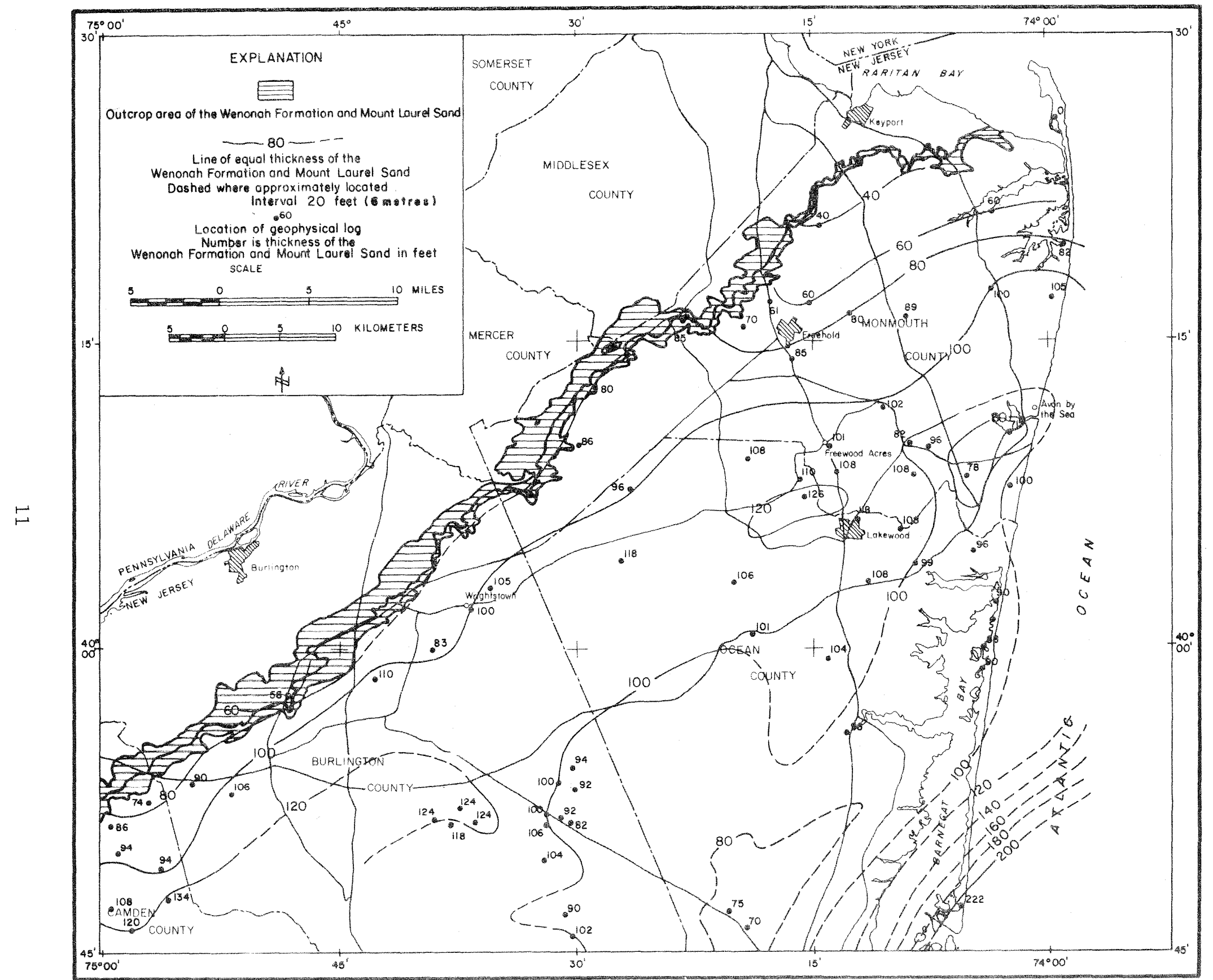

FIGURE S:- THICKNESS OF THE WENONAH FORMATION AND MOUNT LAURLL SAND 


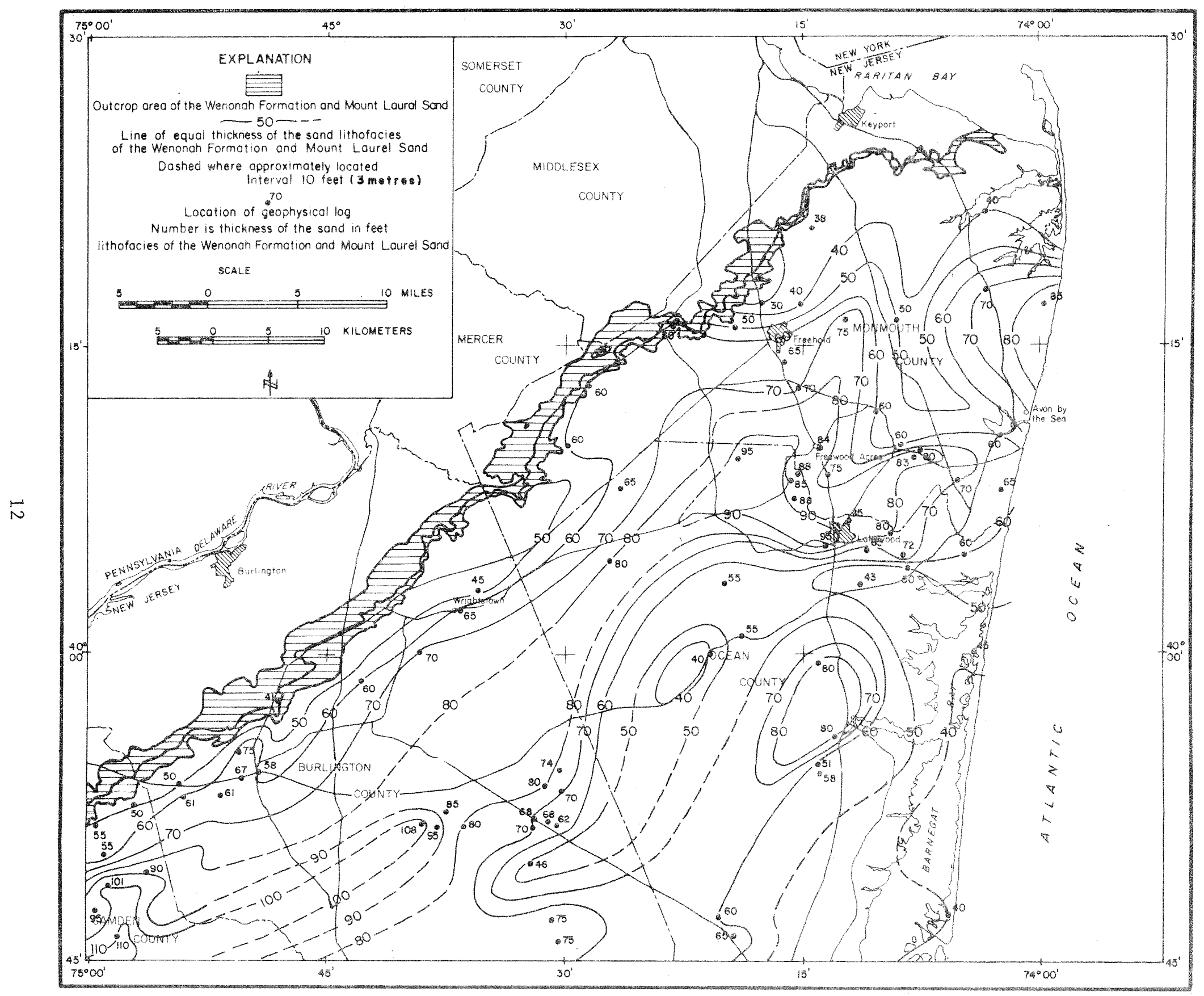

FIGURE 6:- SAND LITHOFACIES THICKNESS OF THE WENONAH FORMATION AND MOUNT LAUREL SAND 
A

NWW OUALL HILLL,
SCOUT RESERVATION

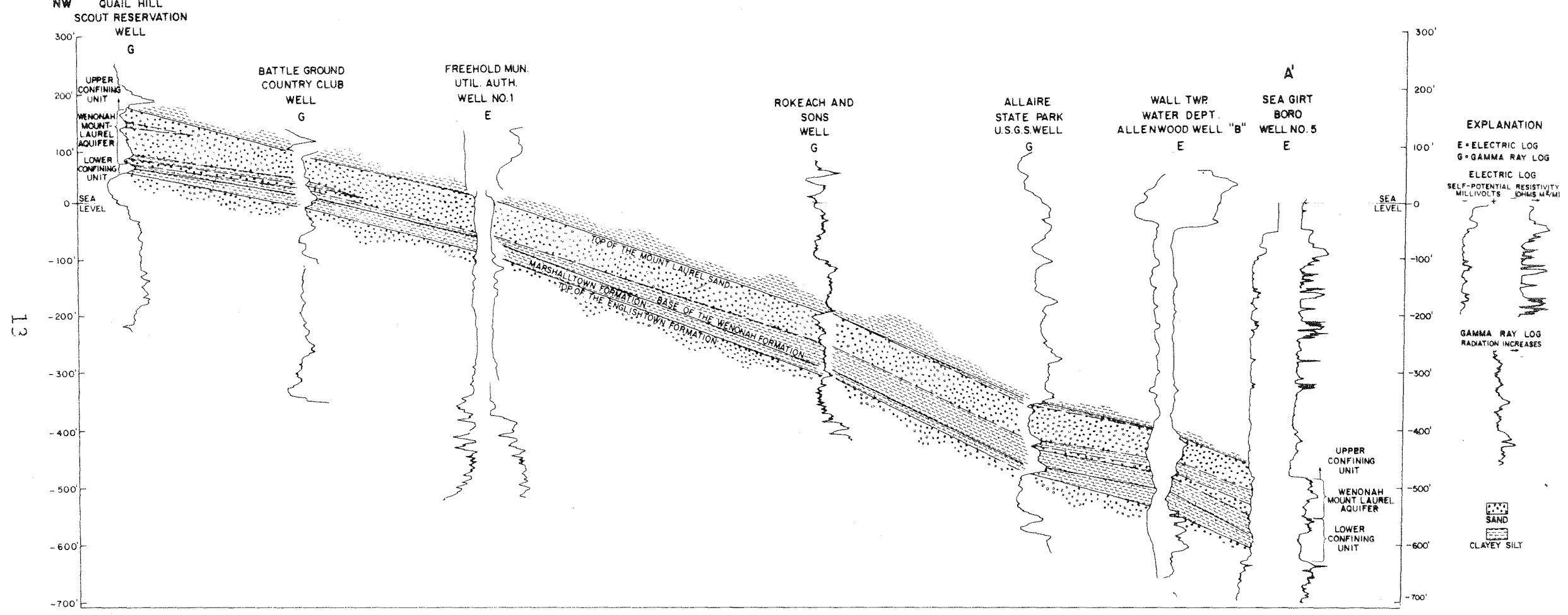

FIGURE 7--SECTION SHOWING THE RELATIONSHIP OF THE WENONAH FORMATION AND MOUNT LAUREL SAND, CONFINING UNITS AND SAND FACIES WITHIN THE WENONAH FORMATION AND MOUNT LAUREL SAND ( 
The Wenonah-Mount Laurel aquifer is underlain by a confining unit which includes the Marshalltown Formation and the lower part of the Wenonah Formation in the northern New Jersey Coastal Plain in Monmouth, Burlington, and Ocean Counties. In the central part of the New Jersey Coastal Plain (Ocean and Burlington Counties), the underlying confining unit includes the Merchantville Formation, Woodbury Clay, Englishtown Formation, Marshal1town Formation, and the lower part of the Wenonah Formation. The overlying confining unit as defined in this report includes all deposits overlying the Mount Laurel Sand.

The thickness of the Wenonah-Mount Laurel aquifer in the northern New Jersey Coastal plain is shown on figure 6. The thickest part of the aquifer is not in the study area but is in central camden, Gloucester, and Salem Counties where it is more than 115 feet $(35 \mathrm{~m})$ thick. The aquifer gradually thins toward the northeast and southeast into Ocean and Monmouth Counties. The outcrop of the upper contact of the Mount Laure1 Sand marks the northwestern boundary of the confined part of the aquifer. The southeastern and eastern boundaries of the aquifer in Ocean and Burlington Counties and beyond the New Jersey coast east of Monmouth and Ocean Counties cannot be defined because of the lack of data.

\section{Wenonah-Mount Laure1 Aquifer}

Hydraulic Characteristics

Three aquifer tests of the Wenonah-Mount Laurel aquifer have been conducted and the results of the tests are listed below:

\begin{tabular}{|c|c|c|c|c|c|c|c|}
\hline \multirow{3}{*}{$\begin{array}{c}\text { Test } \\
\text { Location }\end{array}$} & \multirow[b]{3}{*}{ Year } & \multicolumn{4}{|c|}{ Transmissivity } & \multicolumn{2}{|c|}{ Hydraulic Conductivity } \\
\hline & & \multicolumn{2}{|c|}{$\mathrm{ft} / \mathrm{day}$} & \multicolumn{2}{|c|}{$m^{2} / d a y$} & \multirow{2}{*}{$\begin{array}{l}\mathrm{ft} / \mathrm{sec} \\
\text { Mean }\end{array}$} & \multirow{2}{*}{$\begin{array}{l}\mathrm{m} / \mathrm{sec} \\
\text { Mean }\end{array}$} \\
\hline & & Range & Mean & Range & Mean & & \\
\hline Bradley Beach & 1954 & $360-1,430$ & 670 & $33.4-132.8$ & 62.2 & $2.0 \times 10^{-4}$ & $6.1 \times 10^{-5}$ \\
\hline Salem City & 1965 & -- & 1,200 & $\cdots$ & 111.5 & $1.5 \times 10^{-4}$ & $4.6 \times 10^{-5}$ \\
\hline $\begin{array}{c}\text { Artificial } \\
\text { Island }\end{array}$ & 1968 & $\cdots$ & 940 & $\cdots$ & 87.3 & $2.2 \times 10^{-4}$ & $6.7 \times 10^{-5}$ \\
\hline
\end{tabular}

\begin{tabular}{l|c|c|c}
\hline \multirow{2}{*}{$\begin{array}{c}\text { Test } \\
\text { Location }\end{array}$} & \multicolumn{2}{|c|}{ Coefficient of Storage } & \multirow{2}{*}{ Reference } \\
\cline { 2 - 4 } & Range & Mean & Refley Beach \\
Bradem City & $7.0 \times 10^{-5}-2.1 \times 10^{-4}$ & $1.2 \times 10^{-4}$ & Jablonski, 1968 \\
$\begin{array}{c}\text { Satificial } \\
\text { Island }\end{array}$ & -- & $3.5 \times 10^{-4}$ & Rosenau and others, 1968 \\
\hline
\end{tabular}


Specific-capacity data from industrial and public-supply wells tapping the Wenonah-Mount Laurel aquifer in the New Jersey Coastal Plain were used to estimate transmissivity. The estimation of transmissivity from specific capacity can be calculated by using the following equation (Hurr, 1966).

$$
\begin{gathered}
\mathrm{u}[\mathrm{w}(\mathrm{u})]=1.632 \times 10^{-2}\left(\mathrm{r}^{2} \mathrm{~s} / \mathrm{tQ}\right) \mathrm{Sa} \\
\mathrm{T}=\left(1.87 \mathrm{r}^{2} \mathrm{tu}\right) \mathrm{Sa}
\end{gathered}
$$

where $r=$ the radius of observation of drawdown in feet

$s=$ the drawdown in feet

$t=$ time since pumping began, in days

$\mathrm{Q}=$ discharge in gallons per minute

$\mathrm{Sa}=$ apparent specific yield for a water-table aquifer and storage coefficient for a confined aquifer

$\mathrm{u}[\mathrm{w}(\mathrm{u})]$ is calculated from equation ( 1 ) and $\mathrm{u}$ is then determined graphically from a plot of $u[w(u)] u$. The value of u from the graph is substituted into equation (2) to compute transmissivity in gallons/foot/ day. Dividing the result by 7.48 gives transmissivity values in $f t^{2} / d a y$.

Transmissivity computed from 33 wells ranges from 430 to $1,780 \mathrm{ft}^{2} / \mathrm{day}$ (40 to $165 \mathrm{~m}^{2} /$ day). The average transmissivity for the 33 wells is $790 \mathrm{ft} /$ day $\left(73.4 \mathrm{~m}^{2} /\right.$ day). The specific capacities for the 33 wells range from 2.1 to 10.5 (gal/min)/ft (gallons per minute per foot) $\left[.02\right.$ to $.13\left(\mathrm{~m}^{3} / \mathrm{min}\right) / \mathrm{m}$ (cubic metre per minute per metre)]. The average specific capacity is 4.2 $(\mathrm{gal} / \mathrm{min}) / \mathrm{ft}\left[.05\left(\mathrm{~m}^{3} / \mathrm{min}\right) / \mathrm{m}\right]$. A coefficient of storage of $2.0 \times 10^{-4}$ was used in calculations to estimate transmissivity from specific capacity.

Hydraulic conductivity for the aquifer was calculated by taking the transmissivity of the aquifer at the well site and dividing the transmissivity by the aquifer thickness. The hydraulic-conductivity values were averaged for the 33 wells and the average value of $1.5 \times 10^{-4} \mathrm{ft} / \mathrm{sec}$ (feet per second) $\left[4.6 \times 10^{-5} \mathrm{~m} / \mathrm{sec}\right.$ (metres per second)] was obtained.

The coefficient of storage for the aquifer was taken from two aquifer tests. The mean coefficient of storage for one aquifer test was $1.2 \times 10^{-4}$ and the mean for the second test was $3.5 \times 10^{-4}$.

\section{Water Levels}

The potentiometric surface of the Wenonah-Mount Laurel aquifer in 1959 is shown in figure 8. The 1959 data have been supplemented by water-1eve1 measurements collected in 1958 and 1960 in areas near the outcrop and away from pumping centers, where no significant change in water level occurred from 1958-60. This surface is the beginning of the 12-year period of historic record used to calibrate the simulation model. A second water-level measurement 


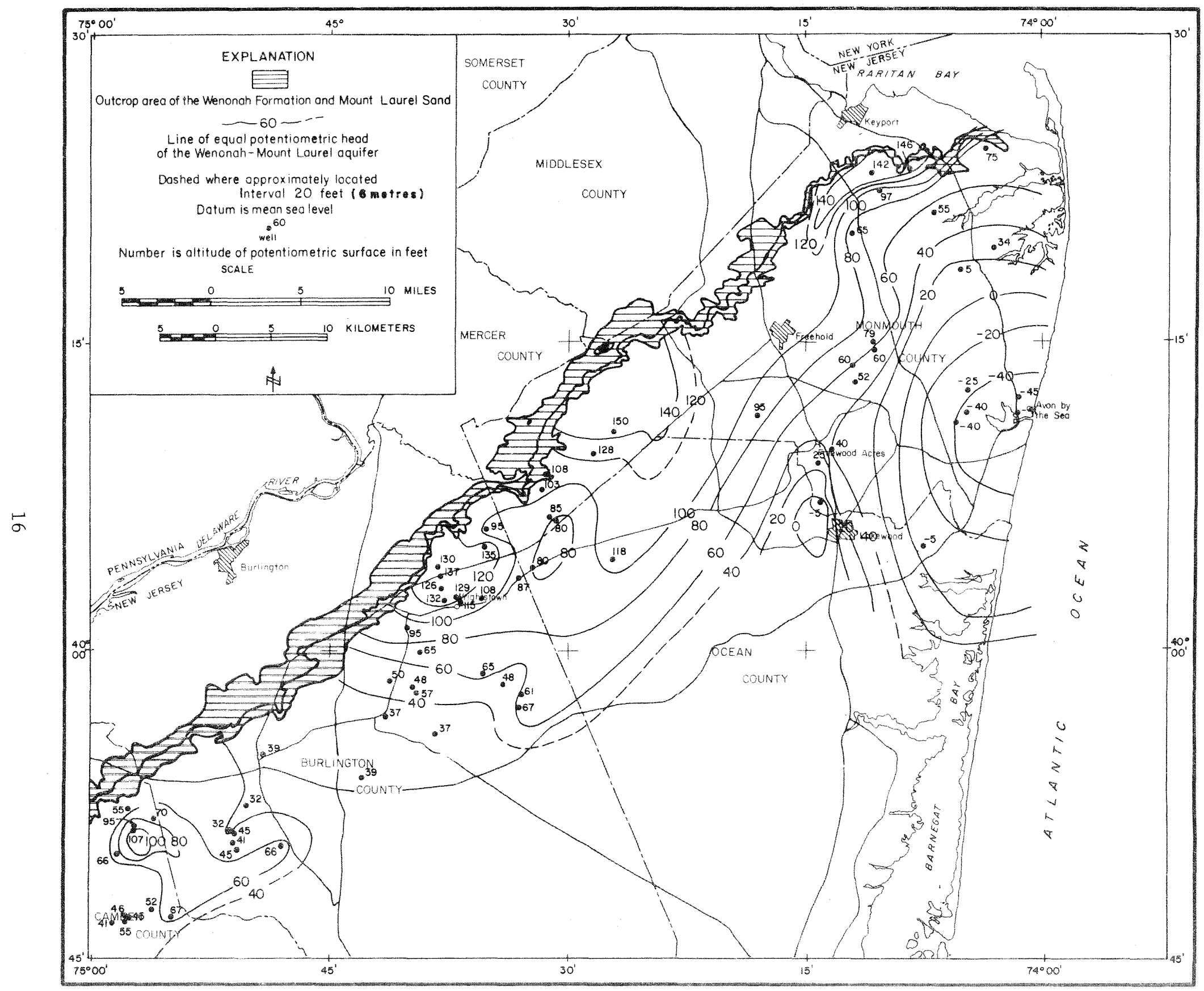

FIGURE 8;--POTENTIOMETRIC SURFACE OF THE WENONAH-MOUNT LAUREL AQUIFER, 1959 
of wells tapping the aquifer was made in November, 1970, which is the end of the 12-year simulation period. The 1970 potentiometric surface is shown in figure 9. The difference in potentiometric surface for the Wenonah-Mount Laurel aquifer from 1959 to 1970 is shown in figure 10. The greatest head decline of approximately 100 feet $(30.5 \mathrm{~m})$ from 1959 to 1970 occurred in the area of Avon-by-the-Sea and Freewood Acres (between Freehold Boro and Lakewood) in Monmouth County. In Burlington County, south of Wrightstown, maximum waterlevel declines were approximately $35 \mathrm{ft}(10.7 \mathrm{~m})$ during the same period.

\section{Recharge}

Recharge to the Wenonah-Mount Laurel aquifer is mainly from downward vertical leakage. The aquifer receives recharge from vertical leakage downdip from the outcrop area where the topographic highs coincide with the potentionetric highs. This coincidence of potentiometric and topographic highs has been shown to occur for the Wenonah-Mount Laurel aquifer and other aquifers in Monmouth County, Burlington County (Rush, 1968, p. 49), Camden County (Farlekas, Nemickas, and Gil1, 1973), and Gloucester County (Hardt and Hilton, 1969, p. 23). Effects of pumping have not reached the potentiometric highs near the outcrop area, and recharge to the Wenonahmount Laurel aquifer is generated by the head difference between the Wenonah-Mount Laurel aquifer and the overlying aquifer system. Natural discharge areas for the aquifer occur along topographic lows in the outcrop area.

\section{Withdrawals}

Pump discharge from the Wenonah-Mount Laurel aquifer domdip from the potentiometric-high areas has developed a cone of depression that is generating downward vertical leakage from the overlying geologic units. The pumping in the subjacent Englishtown aquifer is likewise generating leakage from the Wenonah-Mount Laurel aquifer, through the underlying confining unit and producing additional declines in the Wenonah-Mount Laurel aquifer, which in turn generate leakage from the overlying confining units.

Major withdrawals from the Wenonah-Mount Laurel aquifer (table 2) in the study area are for public supply. Public-supply withdrawals from the aquifer in the study area were at an average rate of about $1 \mathrm{Mgal} / \mathrm{d}(44$ $\left.\mathrm{dm}^{3} / \mathrm{s}\right)$ in 1959 and increased to slightly more than $2.0 \mathrm{Mgal} / \mathrm{d}\left(88 \mathrm{dm}^{3} / \mathrm{s}\right)$ by 1970. Domestic pumpage that occurs in or near the outcrop area of the aquifer is believed to be small and not significant. Withdrawals from the Englishtown aquifer near the coast in Monmouth and Ocean Counties occurred at the rate of $3.5 \mathrm{Mgal} / \mathrm{d}\left(153 \mathrm{dm}^{3} / \mathrm{s}\right.$ ) and at Lakewood, Ocean County, at the rate of $0.7 \mathrm{Mga1} / \mathrm{d}$ (31 $\mathrm{dm}^{3} / \mathrm{s}$ ) in 1959 (Nichols, written commun., 1974). By 1969 the rate of pumping in the Lakewood area had increased to $2.8 \mathrm{Mgal} / \mathrm{d}\left(123 \mathrm{dm}^{3} / \mathrm{s}\right)$ and in the coastal area to $4.1 \mathrm{Mgal} / \mathrm{d}\left(180 \mathrm{dm}^{3} / \mathrm{s}\right)$ (Nichols, written commun., 1974). 


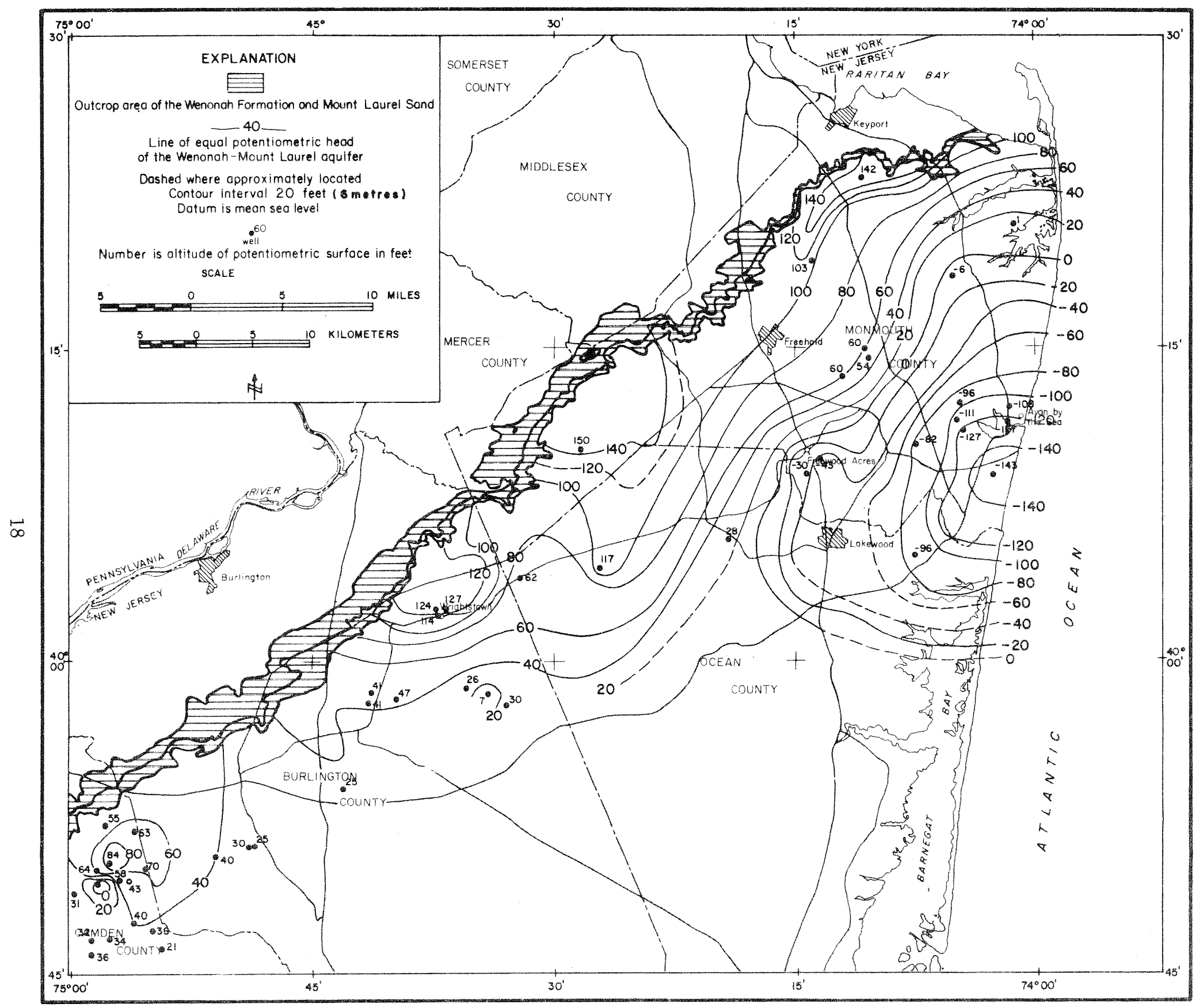

FIGURE 9.-POTENTIOMETRIC SURFACE OF THE WENONAH-MOUNT LAUREL AQUIFER, 1970 


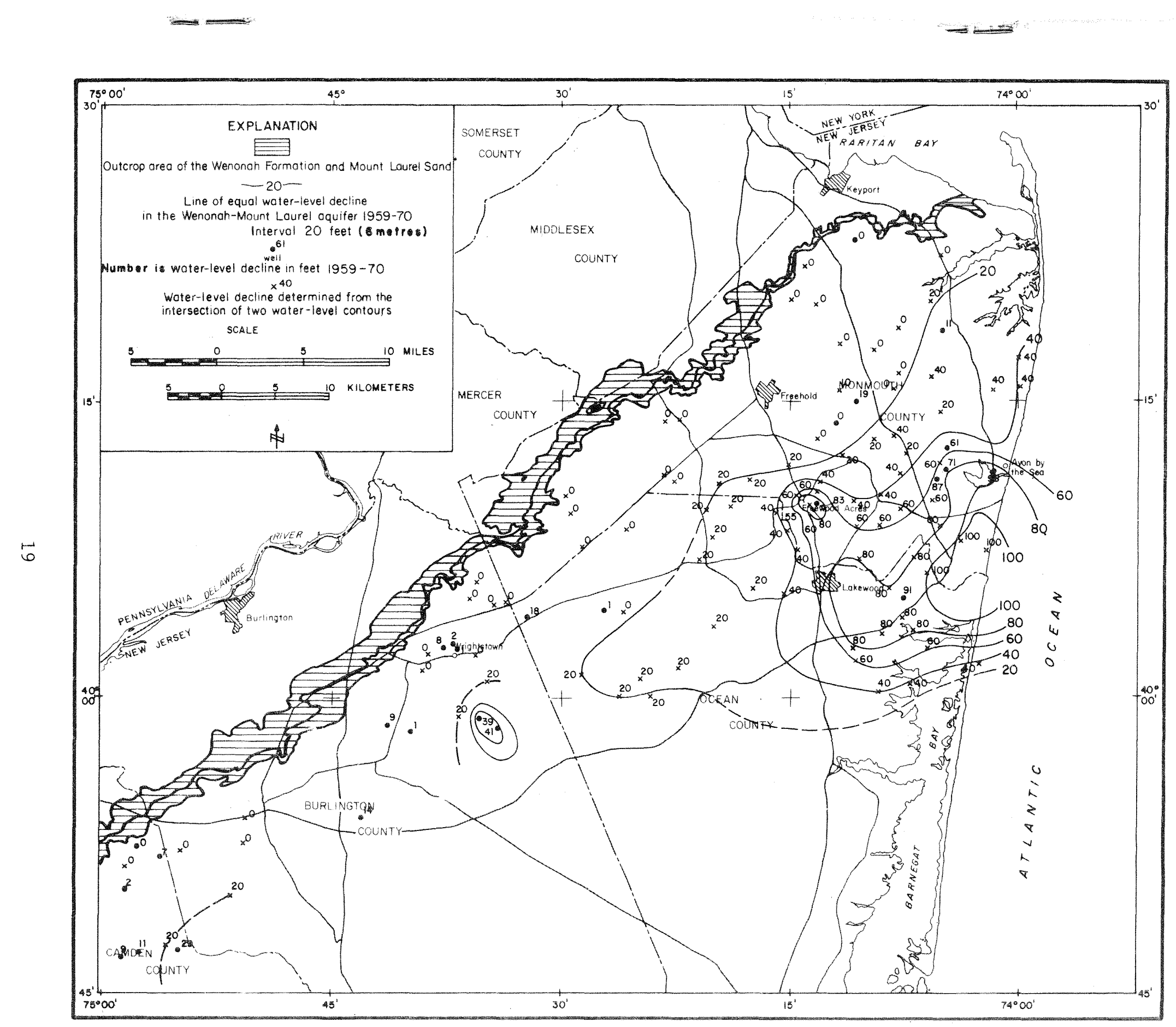

FIGURE 10:-WATER-LEVEL DECLINE IN THE WENONAH-MOUNT LAUREL AQUIFER, 1959-70 
Table 2.--Public-supply withdrawals from the Wenonah-Mount Laurei aquifer from 1959 to 1970.

\begin{tabular}{|c|c|c|c|c|c|c|c|c|c|c|c|c|c|}
\hline \multirow[b]{2}{*}{ Name } & \multirow{2}{*}{$\begin{array}{c}\text { We } 11 \\
\text { number }\end{array}$} & \multicolumn{12}{|c|}{ Pumpage by year, in $\mathrm{Mgal} / \mathrm{d}$} \\
\hline & & 1959 & 1960 & 1961 & 1962 & 1963 & 1964 & 1965 & 1966 & 1967 & 1968 & 1969 & 1970 \\
\hline Avon by the Sea & 1 and 2 & .212 & .212 & .210 & .208 & .212 & .208 & .206 & .260 & .262 & .226 & .214 & .287 \\
\hline $\begin{array}{l}\text { Spring Lake } \\
\text { Heights }\end{array}$ & 1 & .051 & .056 & .060 & .056 & .076 & .082 & .071 & .072 & .079 & .105 & .111 & .132 \\
\hline \multirow[t]{2}{*}{ Wa11 Twp. W.D。 } & Rosehill & $-\cdots$ & -- & -- & .020 & .065 & .087 & .093 & .121 & .173 & .126 & .144 & .150 \\
\hline & Imperial $\mathrm{Pk}$ & -- & -- & - & .128 & .188 & .189 & .208 & .221 & .211 & .268 & .261 & .260 \\
\hline $\begin{array}{l}\text { Monmouth } \\
\quad \text { Consolidated }\end{array}$ & $\begin{array}{l}\text { Ocean } \\
\text { Grove } 2\end{array}$ & .129 & .073 & .061 & .071 & .045 & .053 & .021 & .075 & $\cdots$ & - & .010 & .010 \\
\hline Aldrich W.C. & $1,2, \& 3$ & .051 & .076 & .093 & .130 & .201 & .323 & .356 & .365 & .375 & .331 & .427 & .613 \\
\hline \multirow[t]{3}{*}{ Pemberton Boro } & 1 & .064 & .068 & .077 & .080 & .080 & .081 & .072 & .095 & .088 & .100 & .064 & .077 \\
\hline & 2 & .064 & .068 & .077 & .080 & .080 & .081 & .072 & .095 & .088 & .100 & .017 & - \\
\hline & 3 & - & -- & -- & - & - & -- & -- & -- & -- & - & .024 & .090 \\
\hline \multirow[t]{4}{*}{ Pemberton Twp. } & 2 & $\cdots$ & $\cdots$ & - & $\cdots$ & .010 & .040 & .048 & .051 & .026 & .073 & .075 & .080 \\
\hline & 3 & -- & - & -- & - & .003 & .002 & .067 & .071 & .020 & .057 & .058 & .060 \\
\hline & 4 & .392 & .369 & .360 & .529 & .573 & .488 & .396 & .372 & .404 & .425 & .403 & .403 \\
\hline & 5 & $-\cdots$ & $\cdots$ & $-\cdots$ & - & $-\infty$ & $-\infty$ & $\ldots$ & $\cdots$ & .007 & .014 & .014 & .014 \\
\hline Total & & 0.963 & 0.922 & 0.938 & 1.302 & 1.533 & 1.634 & 1.610 & 1.798 & 1.733 & 1.811 & 1.822 & 2.176 \\
\hline
\end{tabular}


The Wenonah-Mount Laure1 aquifer is bounded above and below by sequences of sandy to clayey silts and silty clays. The underlying sequence of sediments, which forms the lower confining unit for the Wenonah-Mount Laurel aquifer in the northern part of the study area, includes the Marshalltown Formation and the lower part of the Wenonah Formation. The thickness of the lower confining unit in the northern part of the study area ranges from less than $20 \mathrm{ft}(6.1 \mathrm{~m})$ in central Monmouth County to $60 \mathrm{ft}(18.3 \mathrm{~m})$ in western Burlington County to 80 ft $(24.4 \mathrm{~m}$ ) in central Ocean County (fig. 11). The average thickness is about $45 \mathrm{ft}(13.7 \mathrm{~m})$.

In the southern and southeastern part of the study area the lower confining unit is much thicker, including not only the lower part of the Wenonah Formation and the Marshalltown Formation but also the Englishtown Formation (1ocally), Woodbury Clay, and Merchantville Formation. The thickness of the confining unit ranges from $80 \mathrm{ft}(24.4 \mathrm{~m})$ in western Burlington County to $420 \mathrm{ft}(128 \mathrm{~m})$ in southcentral Ocean County. This lower confining unit has an average thickness of $200 \mathrm{ft}(61 \mathrm{~m})$.

Hydraulic conductivity and specific storage values for the lower confining unit were obtained from laboratory tests of undisturbed cores. The range of hydraulic conductivity of the cores is from $3.0 \times 10^{-9} \mathrm{ft} / \mathrm{sec}$ $\left(9.2 \times 10^{-10} \mathrm{~m} / \mathrm{sec}\right)$ to $2.8 \times 10^{-10} \mathrm{ft} / \mathrm{sec}\left(8.5 \times 10^{-11} \mathrm{~m} / \mathrm{sec}\right)$. The specific storage ranges from $1.0 \times 10^{-4} \mathrm{ft}^{-1}\left(3.1 \times 10^{-5} \mathrm{~m}^{-1}\right)$ to $3.4 \times 10^{-6} \mathrm{ft}^{-1}\left(1.0 \times 10^{-6} \mathrm{~m}-1\right)$. Hydraulic conductivity and specific storage were calculated from consolidation test data for the load increment nearest the approximate computed overburden pressure.

\section{Upper Confining Unit}

The sequence of predominantly fine-grained sediments above the Wenonah-Mount Laurel aquifer is treated, in the model, as a single composite confining unit. This composite unit, therefore, consists of the Navesink Formation, Red Bank Sand, Hornerstown Sand, Vincentown Formation, Manasquan Formation, Kirkwood Formation, and the saturated part of the Cohansey Sand and younger sediments, where they are present. The least permeable and thickest part of this upper confining unit in the study area is the Manasquan Formation. The total thickness of the composite upper confining unit ranges from several feet near the outcrop of the aquifer to $1,200 \mathrm{ft}(366 \mathrm{~m})$ in the southeastern corner of the study area (fig. 12). Hydraulic conductivity and specific-storage values were determined from laboratory tests of cores taken in fine-grained sediments at various points in the section above the aquifer. The range of hydraulic conductivity of the cores is from $2.1 \times 10^{-8} \mathrm{ft} / \mathrm{sec}\left(6.4 \mathrm{x} 10^{-9}\right.$ $\mathrm{m} / \mathrm{sec}$ ) to $4.9 \times 10^{-11} \mathrm{ft} / \mathrm{sec}\left(1.5 \times 10^{-11} \mathrm{~m} / \mathrm{sec}\right)$. The specific storage ranges from $3.3 \times 10^{-3} \mathrm{ft}^{-1}\left(1.0 \times 10^{-3} \mathrm{~m}^{-1}\right)$ to $3.1 \times 10^{-6} \mathrm{ft}^{-1}\left(9.5 \times 10^{-7}\right.$ $\mathrm{m}^{-1}$ ). In designing the digital model, it was assumed that the properties 


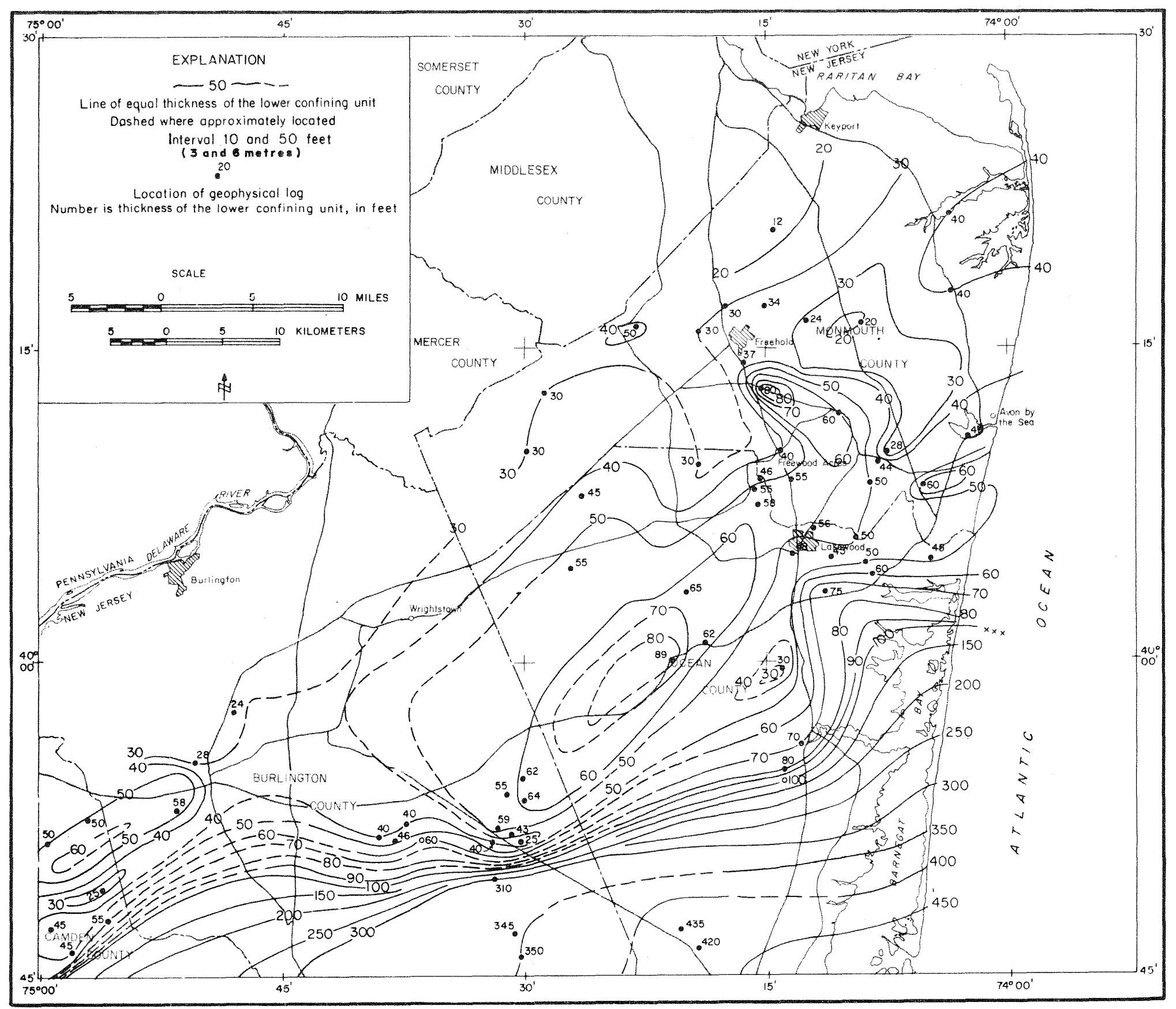

FIGURE II:-THICKNESS OF THE LOWER CONFINING UNIT 


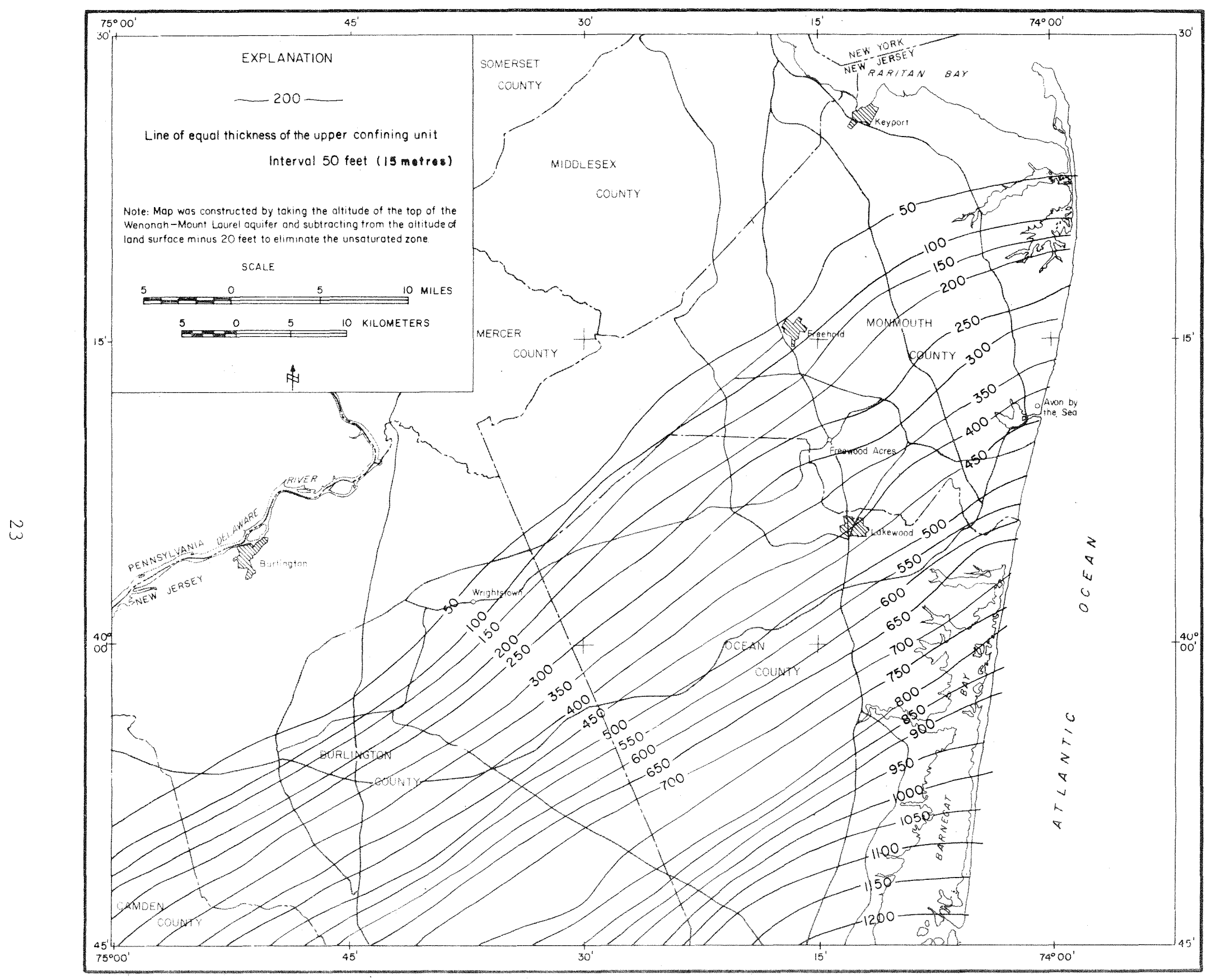

FIGURE 12:-THICKNESS OF THE UPPER CONFINING UNIT 
of the composite upper confining unit were represented largely by the fine-grained materials of the section and, therefore, fell within the ranges determined for the cores.

\section{AQUIFER SIMULATION}

The use of digital computers in ground-water resources evaluation has been established in the past few years. Computers are available that allow solutions of a large set of simultaneous equations that are involved in studying the cause and effect relationships in heterogeneous aquifer systems having a wide variety of source and sink functions and boundary conditions. In this report, the computer program used to simulate the Wenonah-Mount Laurel aquifer is based on a program developed by Pinder (1970) and modified by Trescott (1973). The program is written in FORTRAN IV for the IBM System 360.

The program simulates the response of a confined aquifer system to pumping from one or more wells by solving the two-dimensional groundwater flow equation. The aquifer system may be irregular in shape and may be nonhomogeneous. Steady and transient leakage from overlying and underlying confining units are included. The simulation is carried out using a sequence of pumping periods; pumping rates during each pumping period are constant, but may be changed from period to period.

The differential equation for nonsteady flow of a noncompressible fluid in an elastic nonhomogeneous porous medium can be written (Pinder and Bredehoeft, 1968):

$$
\frac{\partial}{\partial x_{i}}\left(T_{i j} \frac{\partial h}{\partial x_{j}}\right)=S \frac{\partial h}{\partial t}+W(x, y, t)
$$

where $T_{i j}$ is the transmissivity tensor $\left(\mathrm{L}^{2} / \mathrm{T}\right)$;

$h$ is the hydraulic head (L);

$S$ is the storage coefficient (dimensionless);

$t$ is time $(T)$;

$\mathrm{W}$ is the volumetric flux of inflow to outflow from the aquifer, per unit surface area of aquifer $(\mathrm{L} / \mathrm{T})$. In the model used in this study, W, included pumpage and leakage through overlying and underlying confining beds.

The digital-modelling technique provides approximate solutions to equation (1) for specified boundary conditions. A rectangular mesh is superposed on a map of the aquifer, dividing it into elements or blocks. A node is located at the center of each block; and the head at each node, at any given time, is related to the heads at surrounding nodes through 
a finite-difference approximation to equation ( 1 ). Time is "discretized" by dividing the time axis into increments or steps; the head at a given node is treated as constant within a time increment and is assumed to vary in stepwise fashion from one time increment to the next. This procedure gives rise to a set of $N$ simultaneous algebraic equations for any given time step, where $\mathrm{N}$ is the number of nodes in the mesh. The equation set for each time step is solved by an iterative process, as described by Trescott (1973), in which the computations are processed alternately in the $\mathrm{x}$ and $\mathrm{y}$ directions. The technique is commonly referred to as the iterative-altemating direction-implicit procedure,

The model as described by Trescott provides for vertical leakage from an overlying source bed, through a confining layer, and for transient leakage of water derived from storage within the confining layer itself. The model as used in this study was modified to allow for leakage from an underlying source bed, as well, and for transient leakage of water derived from storage in the underlying confining unit.

At each node the following information is recorded as data input sets:

1) lateral hydraulic conductivity of the modelled aquifer; vertical hydraulic conductivity of the upper confining unit and lower confining unit;

2) specific storage of the modelled aquifer; specific storage of the upper and lower confining units;

3) pumping rate at each node where a production well tapping the modelled aquifer is located (A negative value can be used to indicate a recharge we11);

4) thickness of aquifer, upper confining unit, and lower confining unit;

5) water-table surface in the overlying aquifer and potentiometric head in the underlying aquifer;

6) dimensions of the elements of the rectangular grid;

7) initial potentiometric surface of the modelled aquifer;

8) rate of change in the potentiometric surface of the underlying aquifer.

The purpose of the program is to calculate the hydraulic head in the aquifer as a function of space and time. Numerical values and an alphameric contour map of the drawdown in the aquifer are printed at selected time steps. 
For a detailed explanation of the method used for solving the finite-difference equations and obtaining approximate solutions of partial differential equations see Pinder (1970); Trescott, (1973); and Von Rosenberg (1969).

\section{Problem-Solving Capabilities}

Evaluation of the response of an aquifer system to a given stress is possible with the simulation model. Once historic events are reproduced by the simulation mode1, and if it is a valid representation of the ground-water flow system, then the simulation model, with the Iimiting assumptions, can be used to investigate and provide answers to a variety of ground-water resources problems.

The groundwater problems that can be investigated and evaluated by the aquifer simulation model are:

1) predict the rate and magnitude of water-level decline over the next 10 to 20 years under any given pumping regime in the modelled aquifer;

2) evaluate the effects of increased or decreased ground-water withdrawals at any node in the aquifer;

3) evaluate ground-water diversion effects at specific locations before granting such diversions;

4) evaluate the ground-water supply potential of currently underdeveloped areas;

5) evaluate the potential of artificial recharge in selected areas;

6) evaluate the effects, on the modelled aquifer, of changes of the potentiometric surface of the underlying aquifer.

\section{SIMULATION OF THE WENONAH-MOUNT LAUREL AQUIFER SYSTEM}

The Wenonah-Mount Laurel digital model was developed gradually during the study period from a hydrologically simple model to a moxe complex quasi-multilayer model with leakage. The present digital model is based on a computer program developed by Pinder (1970). Departure from the standard model consists of the use of two confining beds, two adjacent aquifer head distributions, a stepwise head change in the subjacent aquifer, and the use of variable hydraulic conductivity and specific storage for the two confining units. 
The model was continually refined by the acquisition of new data during the initial phase of model development. These data included water levels, hydraulic conductivity, specific storage, thickness, and pumpage for the modelled aquifer; hydraulic conductivity, specific storage, thickness data for the adjacent confining beds; and waterlevel declines for the Englishtown aquifer. The final model uses a 47 x 87 node grid (fig. 13) with variable node spacing ranging from $1 / 2$ mile to 19 miles. The half a mile square grid spacing was used for the area with the greatest water-level declines in Monmouth and Ocean Counties.

\section{Boundary Conditions}

Few data are available to determine the boundaries of the modelled aquifer dowdip from the outcrop. Hydrologic data for the offshore area are not avaliable, and estimates of hydrologic parameters were used in the mode1. The northeastern boundary of the model is specified as an impermeable boundary and has been located $20 \mathrm{mi}(32 \mathrm{~km}$ ) to the northeast of Raritan and Sandy Hook Bays. The boundary was located at this distance so that it would not influence the mathematical calculations generated by the model and there is no direct hydraulic connection between the bays and the aquifer. The northern part of the southeastern boundary of the model lies offshore in the Atlantic Ocean and the southern part is in Ocean, Burlington, and Atlantic Counties. The southeastern boundary also is specified in the model as an impermeable boundary and has been located sufficiently far from the pumping centers so that any influence of this boundary on the areas of primary dynamic response was insignificant. The southwestern boundary of the model is Delaware Bay. Because there is no direct hydraulic connection between the aquifer and the bay, and little pumpage takes place from the WenonahMount Laurel aquifer in the southern Coastal Plain, an impermeable boundary is designated for modelling purposes.

The northwestern border of the model coincides with the upper contact of the Mount Laurel Sand along i.ts outcrop area. The outcrop area is known to be both a discharge and recharge area of the aquifer. The topographic highs are the recharge areas and the lows are the discharge areas. Discharge and recharge rates along the boundary are not known, and the boundary is specified as a constant-head boundary in the model.

\section{Aquifer and Upper and Lower Confining Unit Data}

Thickness, hydraulic conductivity, and specific storage values for the Wenonah-Mount Laurel aquifer are recorded for each node in the model. The aquifer thickness data set is used to generate the transmissivity and storage coefficient arrays by multiplying each thickness value by a value of hydraulic conductivity to obtain transmissivity and specific storage to obtain storage coefficient. The transmissivity and storage coefficient values used in the model are shown in figures 14 and 15. 


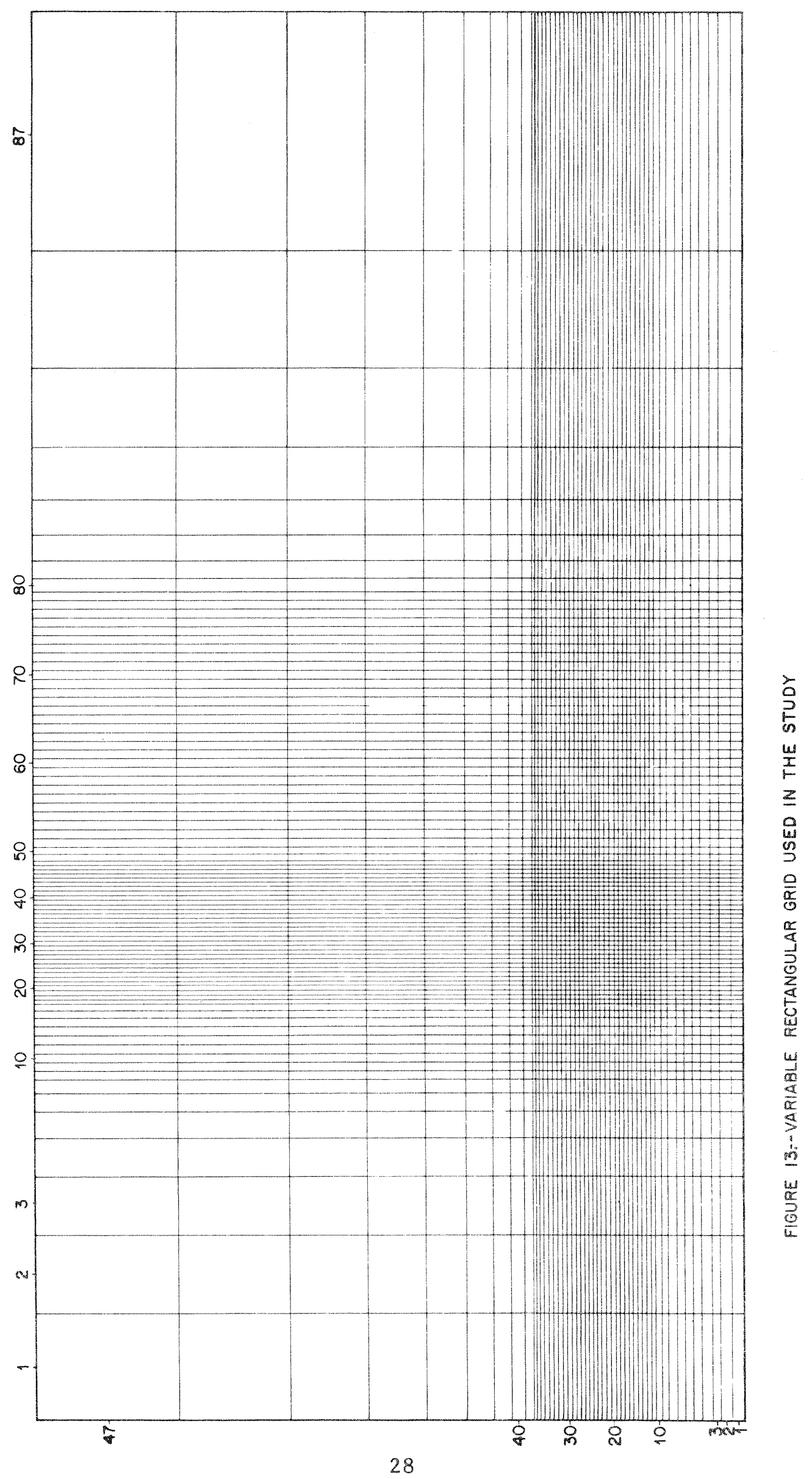




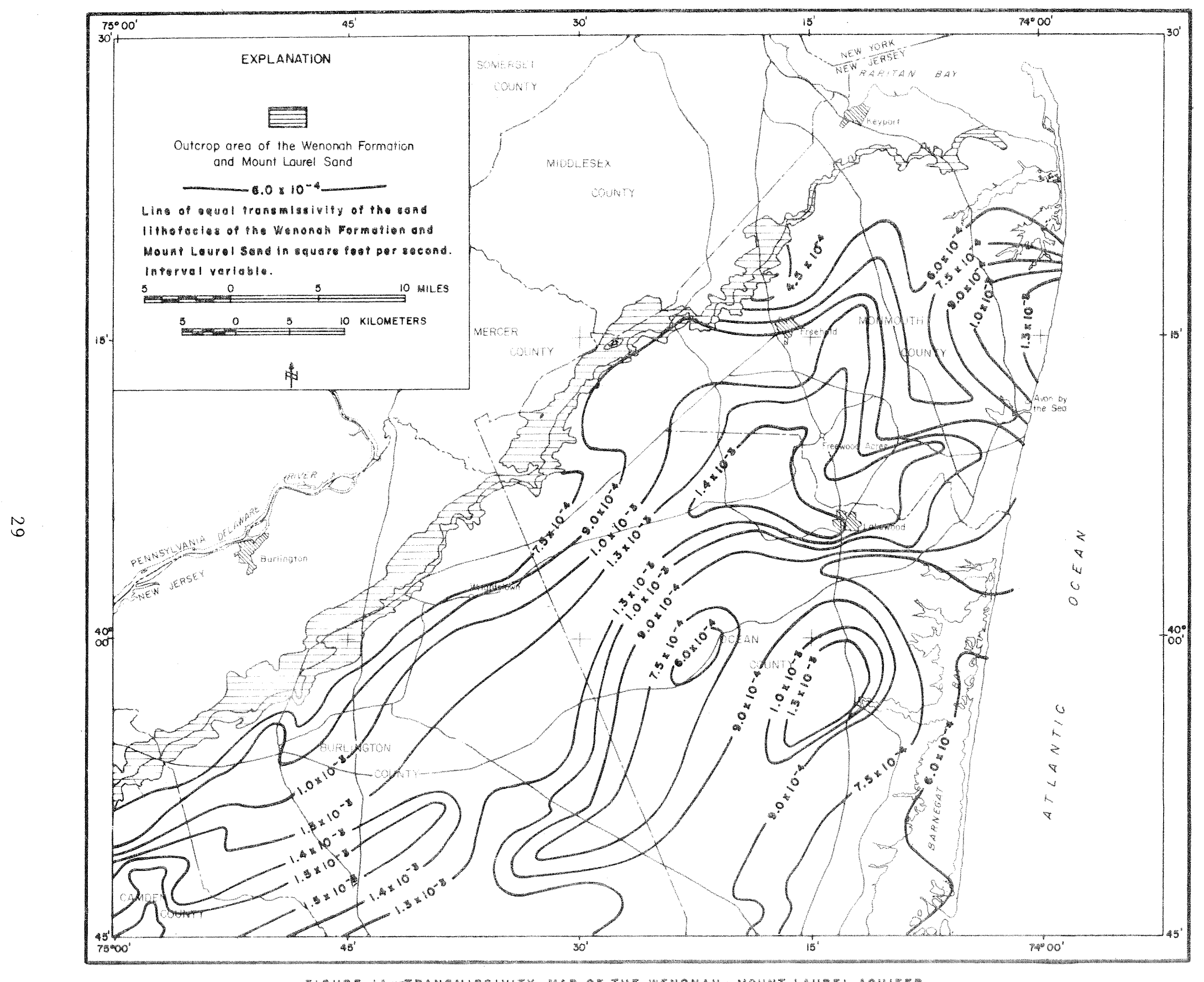

FI UUR I A 


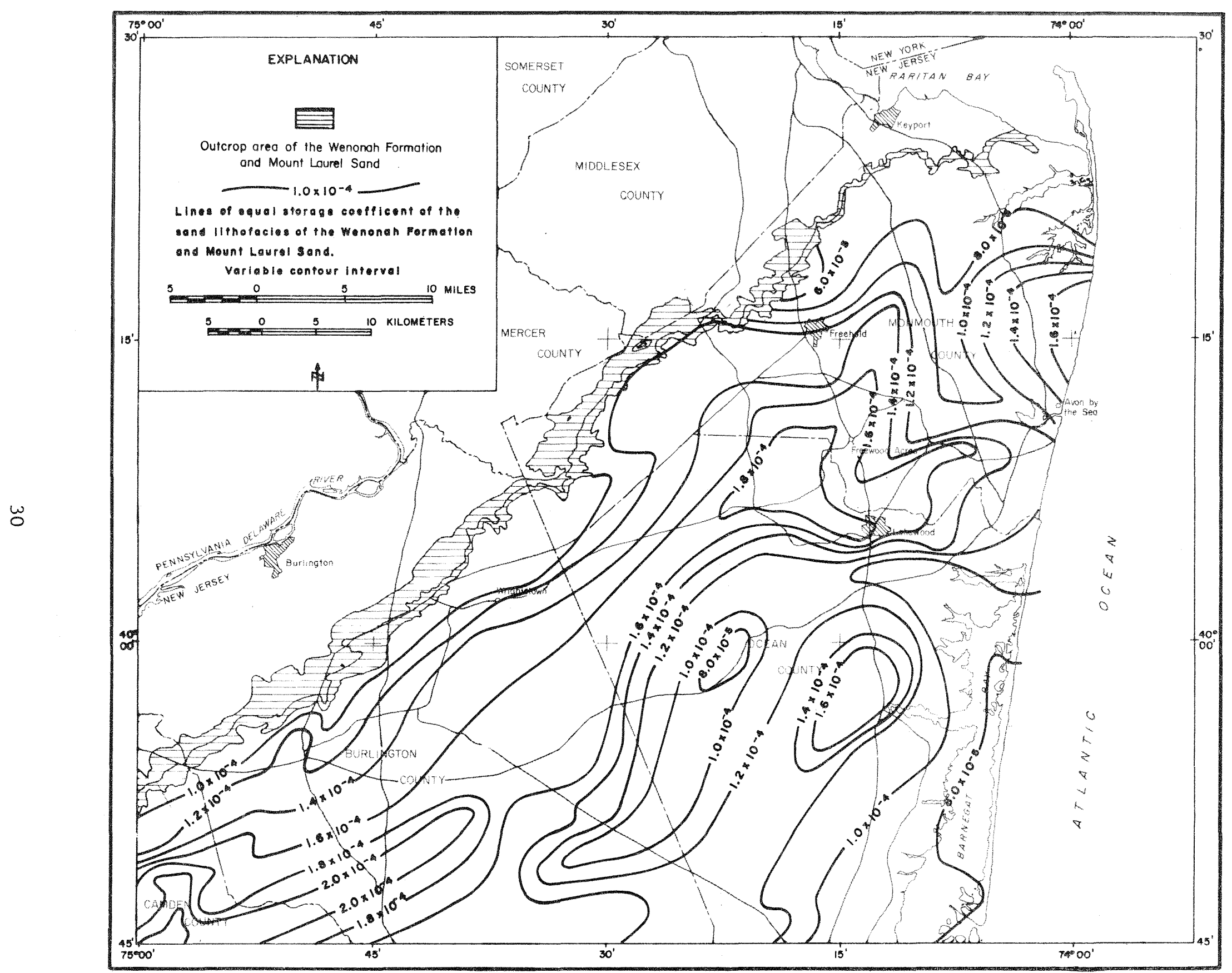

PIGURE 15.--STORAGE COEFFICIENT MAP OF THE WENONAH-MOUNT LAUREL AQUIFER. 
A constant average hydraulic-conductivity value (table 3) was used in the mode1. The average value was determined from 33 wells in the study area. A constant specific-storage value (table 3) was also used in the model to generate a variable storage coefficient for the WenonahMount Laurel aquifer. The specific storage values determined from aquifer tests did not produce enough drawdown as that recorded in the field; therefore, in order to increase the declines in the stressed area, the specific storage value was decreased to $2.5 \times 10^{-5} \mathrm{ft}^{-1}$ $\left(6.1 \times 10^{-6} \mathrm{~m}^{-1}\right)$. Other arbitrary, but equal1y plausible, specificstorage values were tested in the mode1, producing very little change on the drawdown in the aquifer.

Table 3.--Hydraulic parameters used in the Wenonah-Mount Laurel aquifer-simulation model

\begin{tabular}{|c|c|c|c|c|c|c|}
\hline & \multicolumn{4}{|c|}{ Hydraulic conductivity } & \multirow{2}{*}{\multicolumn{2}{|c|}{$\begin{array}{l}\text { Specific } \\
\text { storage }\end{array}$}} \\
\hline & \multicolumn{2}{|c|}{ Maximu m } & \multicolumn{2}{|c|}{ Minimum } & & \\
\hline & $\mathrm{Et} / \mathrm{sec}$ & $\mathrm{m} / \mathrm{sec}$ & $\mathrm{Et} / \mathrm{sec}$ & $\mathrm{m} / \mathrm{sec}$ & $\mathrm{et} \mathrm{t}^{-1}$ & $m^{-1}$ \\
\hline $\begin{array}{l}\text { Wenonah-Mount Laurel } \\
\text { aquifer }\end{array}$ & $1.5 \times 10^{-4}$ & $4.6 \times 10^{-5}$ & $1.5 \times 10^{-4}$ & $4.6 \times 10^{-5}$ & $2.0 \times 10^{-5}$ & $6.1 \times 10^{-6}$ \\
\hline Upper confining unit & $9.5 \times 10^{-9}$ & $2.9 \times 10^{-9}$ & $6.0 \times 10^{-10}$ & $1.8 \times 10^{-10}$ & $3.5 \times 10^{-5}$ & $1.1 \times 10^{-5}$ \\
\hline Lower confining unit. & $9.9 \times 10^{-9}$ & $3.0 \times 10^{-9}$ & $8.0 \times 10^{-10}$ & $2.4 \times 10^{-10}$ & $6.0 \times 10^{-5}$ & $1.8 \times 10^{-5}$ \\
\hline
\end{tabular}

Thickness, hydraulic conductivity, and specific storage for each confining layer are recorded for all nodes in the model. These data are used to compute the coefficients needed to calculate transient and steady leakage rates at each node.

A constant specific-storage value for each confining unit (table 3) was used in the model, because it was the least sensitive parameter. A constant hydraulic-conductivity value was tried for each confining unit that produced poor results. The model indicated that slight changes in hydraulic conductivity of confining layers are extremely sensitive and produced large drawdown variations in the aquifer. A range in hydraulic conductivity for the confining layers was established from lahoratory analyses of undisturbed cores. This range was the limit of adjustment in hydraulic conductivity for the confining units in the model.

\section{Water Table and Potentiometric Head Data}

The 1959 potentiometric surface for the Wenonah-Mount Laurel aquifer (fig. 8) is the initial or starting water-level condition for the stressed aquifer in the model for the calibration period. The 1970 potentiometric surface (fig. 9) for the Wenonah-Mount Laurel aquifer is the final waterlevel condition in the model for the 12-year calibration period. Water levels at more than 40 points were used to construct the 1970 potentiometric surface and to calibrate the model. 
The generalized water-table surface for the overlying unconfined aquifer above the upper confining unit (fig. 16) was constructed from topographic maps. Altitudes of selected points where streams crossed contour lines were plotted and contoured. This surface was used in the mode1. Water-level data from observation wells and drillers" logs indicate that the water-table surface did not change substantially during the period 1959-70. Hence, the water-table surface above the upper confining unit was held constant for all simulation runs.

The potentiometric surface of the Englishtow aquifer, which underlies the lower confining unit, was used in the simulation model. The initial or starting head is the 1959 potentiometric head (fig. 17). Englishtownaquifer water levels have been declining at a rate of 8 to 12 ft per year in southern Monmouth-northern Ocean Counties (Nichols, written commun., 1974). Therefore, in order to simulate more accurately the effect of declining water levels of the Englishtown aquifer on the Wenonah-Mount Laurel aquifer, the Englishtown water levels used in the model were also lowered. The total decline in the Englishtown aquifer for the calibration period 1959-70 is shown in figure 18. The initial, 1959, head was used for the first pumping period. Thereafter, the head was lowered at each node at two-year intervals at a rate equal to the total 12-year decline divided by six. This generated a step type of adjustment in the head of the Englishtown aquifer at specific intervals during the calibration. period.

\section{Pumpage Data}

Pumpage data, in million gallons per day, are entered into the model for each node with a pumping well or well field. An average rate of pumping for each 2-year period was used in the mode1. At the start of each new pumping period, the average rate of pumping was adjusted to the new calculated rate of pumping for the 2-year period being simulated. The simulation model incorporates a total of six 2-year pumping periods for the total calibration period.

\section{CALIBRATION OF THE WENONAH-MOUNT LAUREL STMULATION MODEL}

The water-level decline computed by the simulation model for the period 1959-70 is shown in figure 19. Comparing figure 19 with the 1959-70 potentiometric-difference map of the Wenonah-Mount Laure1 aquifer ( $\mathrm{fig}, 10$ ), one can see that there is close agreement between computed and measured field declines throughout most of the area. Somewhat different declines near the pumping centers $( \pm 10 \mathrm{ft})( \pm 3.1 \mathrm{~m})$ have been computed by the simulation model than were interpreted from available field data. The small differences between the computed and field declines result partly from the fact that the location of pumping wells does not coincide with the center of grid nodes in the model. Also the small number of available wells (26 wells) that had both 1959 and 1970 water-level measurements required interpretive contouring over 


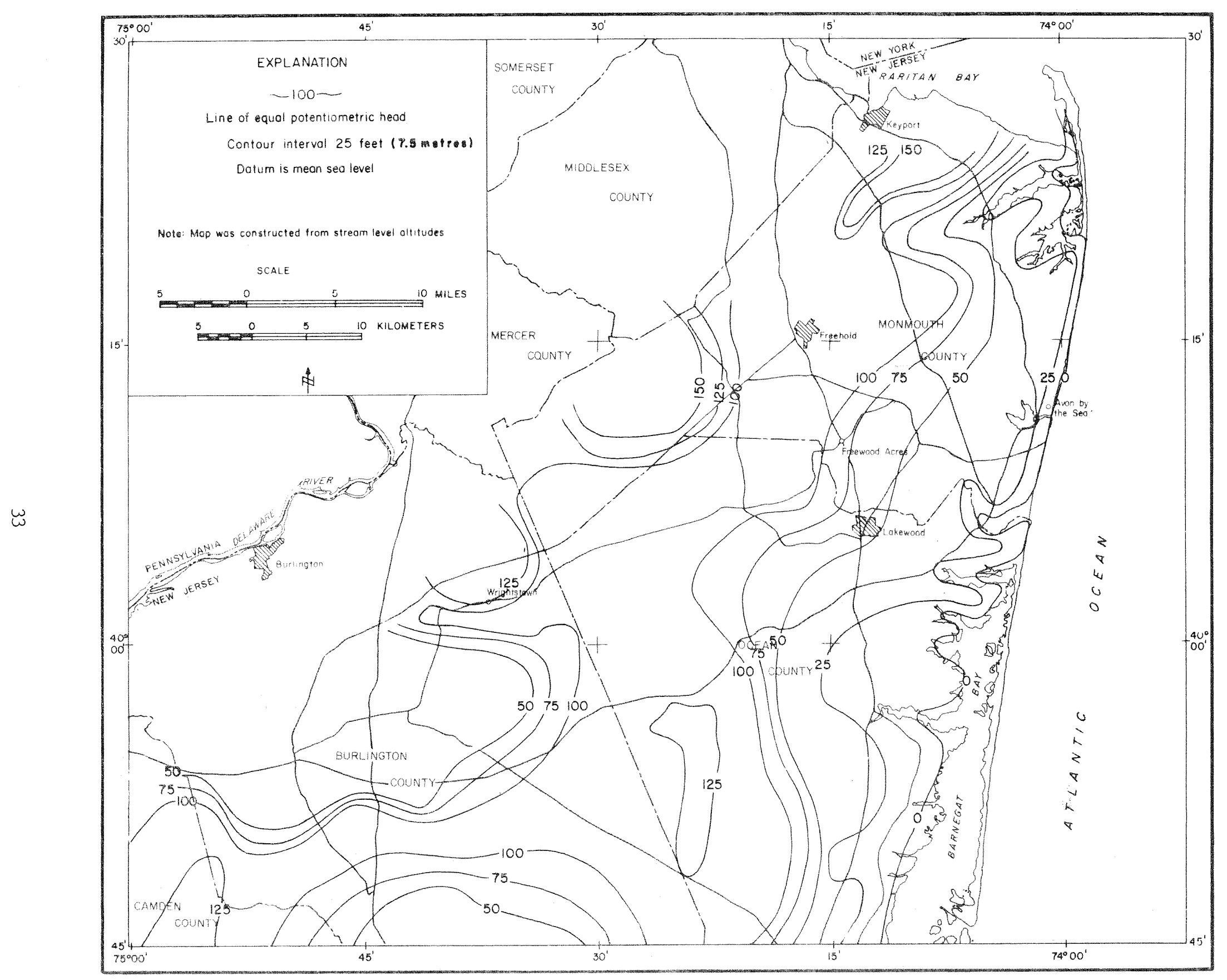

FIGURE IGMGENERALIZED WATER TABLE MAP 


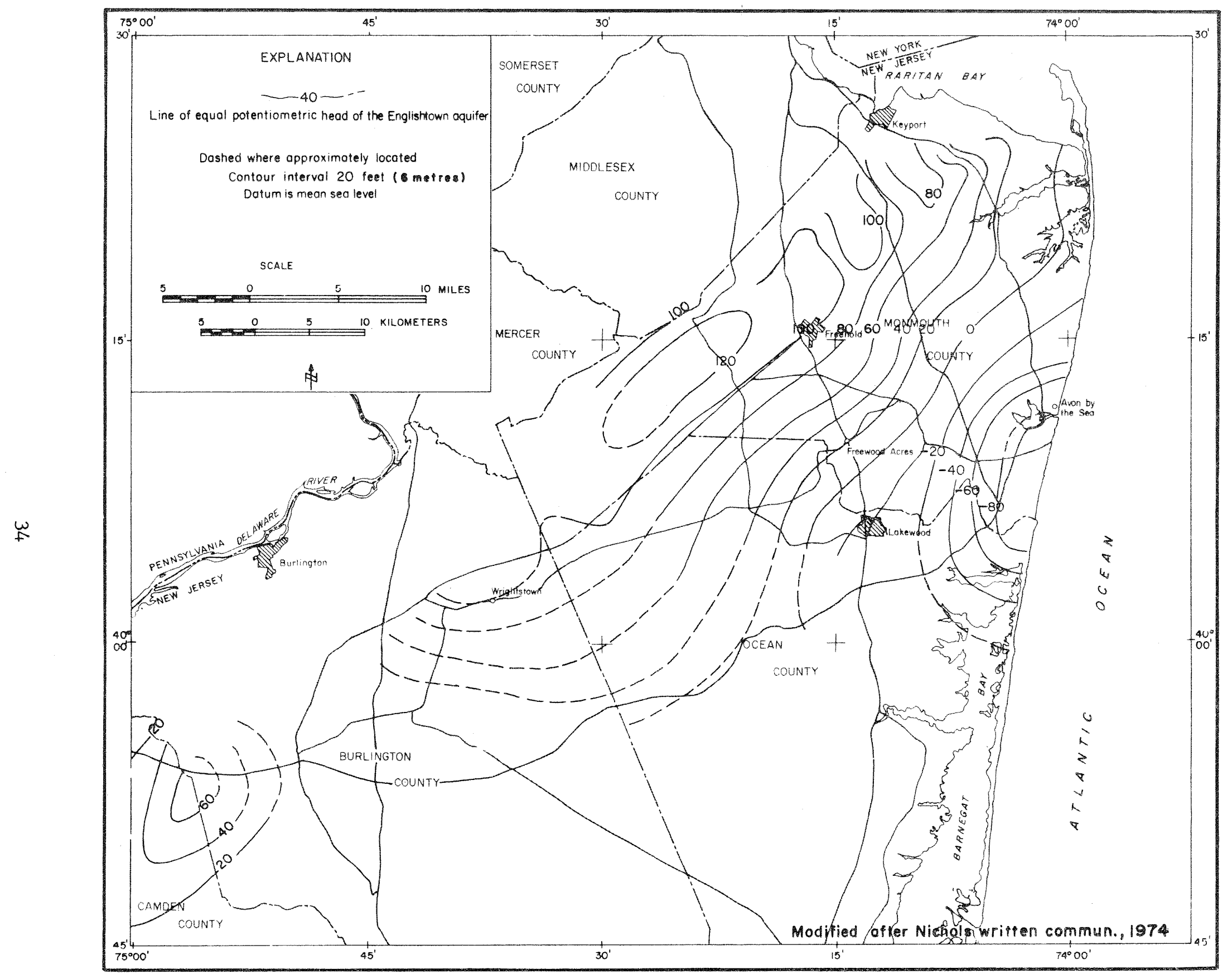

FIGURE 17.-POTENTIOMETRIC MAP OF THE ENGLISHTOWN AQUIFER, 1959 


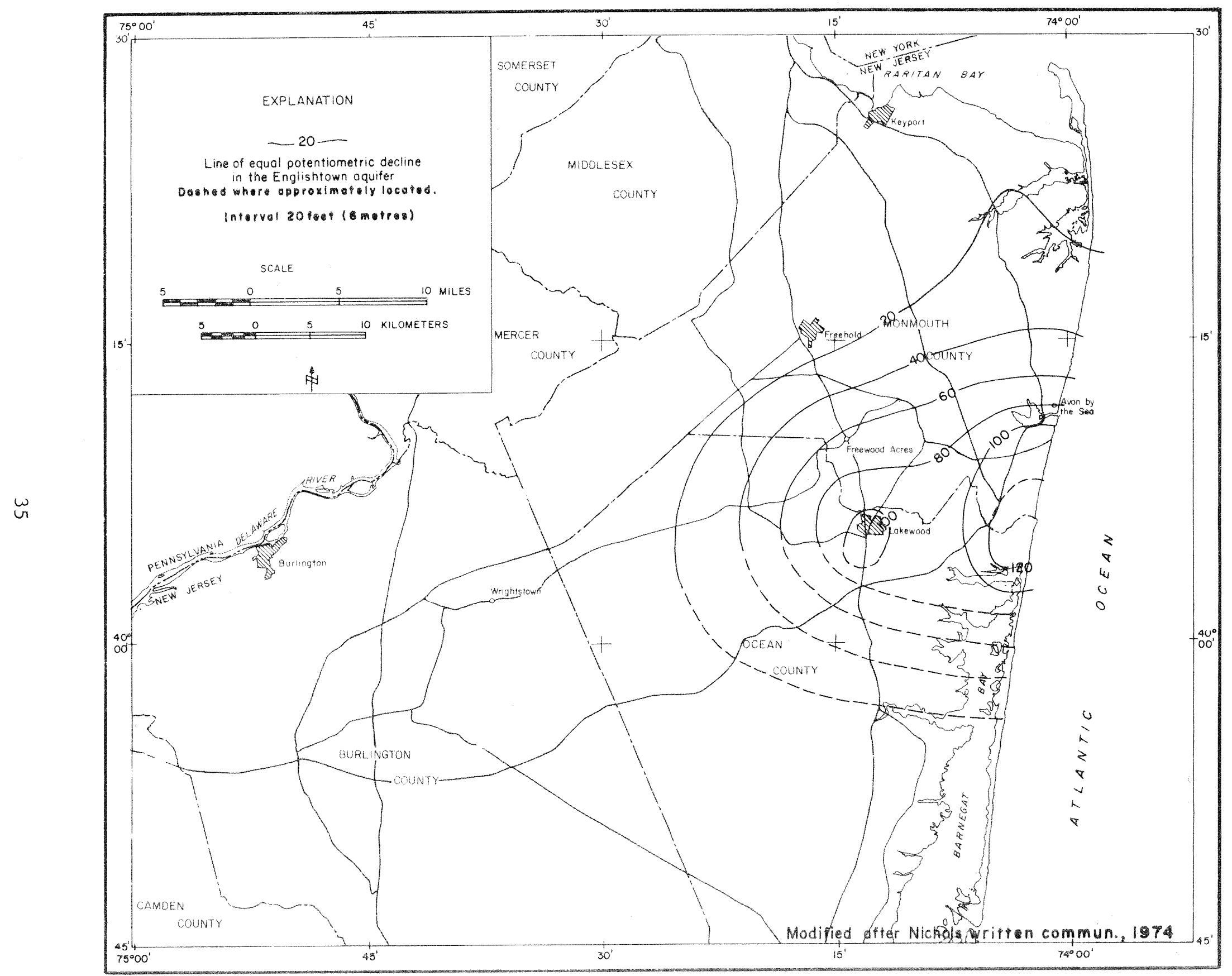

FIGURE 18.DECLINE IN POTENTIOMETRIC SURFACE IN THE ENGLISHTOWN AOUIFER, 1959-70 


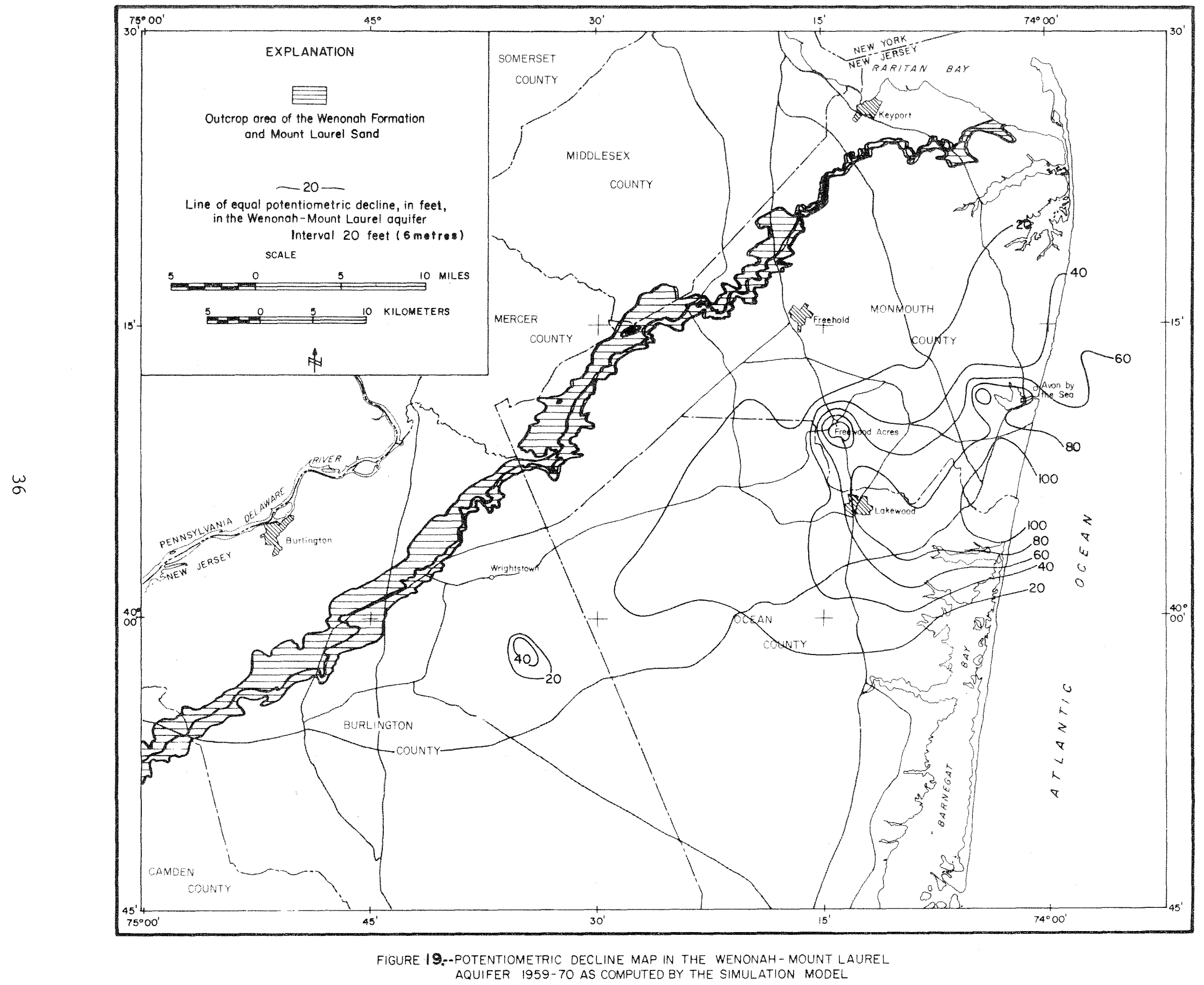


large areas. Water-level altitudes were determined by field measurements and from wel1 records for 1959. In 1970 water-level measurements were repeated in only 26 of the wells that were measured in 1959. Different wells in 1959 and 1970 were also used as data points for the construction of water-level maps. The altitude of water levels is determined by field measurements by measuring depth to water to the tenth of a foot. These data are subtracted from the altitude of the land surface as estimated from topographic maps with 10 or $20 \mathrm{ft}$ ( 3.1 or $6.1 \mathrm{~m}$ ) contours, which may cause inaccuracies of $10 \mathrm{ft}(3.1 \mathrm{~m})$ or more in the wells where only one measurement was obtained in 1959 or in 1970. Despite the possible inaccuracies that may exist in the methodology, the computed total decline (fig. 19) for the calibration period is very similar to the field declines (fig, 10).

Based on the calibration of the model, a test was run to determine the effect of leakage between aquifers on the decline of the WenonahMount Laurel head. The model was run for the 12-year simulation period only, with the step-like decline in the Englishtown aquifer and the elimination of pumpage in the Wenonah-Mount Laurel aquifer. The results of the test indicated that the decline in the Wenonah-Mount Laure1 aquifer, without pumpage, was about two-thirds of the total decline. Therefore, it is concluded that the major cause of the water-1evel decline in the Wenonah-Mount Laurel aquifer can be attributed to the stress in the Englishtown aquifer and only one-third of the decline is due to direct withdrawals from the Wenonah-Mount Laurel aquifer.

\section{PREDICTIONS}

The calibrated Wenonah-Mount Laurel simulation mode1 was run for an additional 8 years from 1971 to 1978. The head for the Englishtown aquifer for the additional period was lowered at the same annual rate as that used for the period 1959-70. Figure 20 represents the total decline that can be expected from 1959 to 1978 if pumpage from the Wenonah-Mount Laurel aquifer remained at the 1970 rate of $2.2 \mathrm{Mgal} / \mathrm{d}$ $\left(96 \mathrm{dm}^{3} / \mathrm{s}\right)$ and with the same distribution as in table 2; the Englishtown heads continued to decline 8 to $12 \mathrm{ft}(2.4$ to $3.7 \mathrm{~m})$ per year in southern Monmouth and northern Ocean Counties.

This prediction indicates that an additional $60 \mathrm{ft}(18.3 \mathrm{~m})$ of water-level decline can be expected for the Wenonah-Mount Laurel aquifer at the Englishtown centers of pumping and an additional $20 \mathrm{ft}(6.1 \mathrm{~m})$ of water-level decline will develop on the fringes of the present WenonahMount Laurel cone of depression from 1971 to 1978.

\section{ModeI Limitations}

The major limitation of the model is the assumption that has to be made for the Englishtown-aquifer head distribution when future conditions are predicted. The model can be used to calculate predicted 


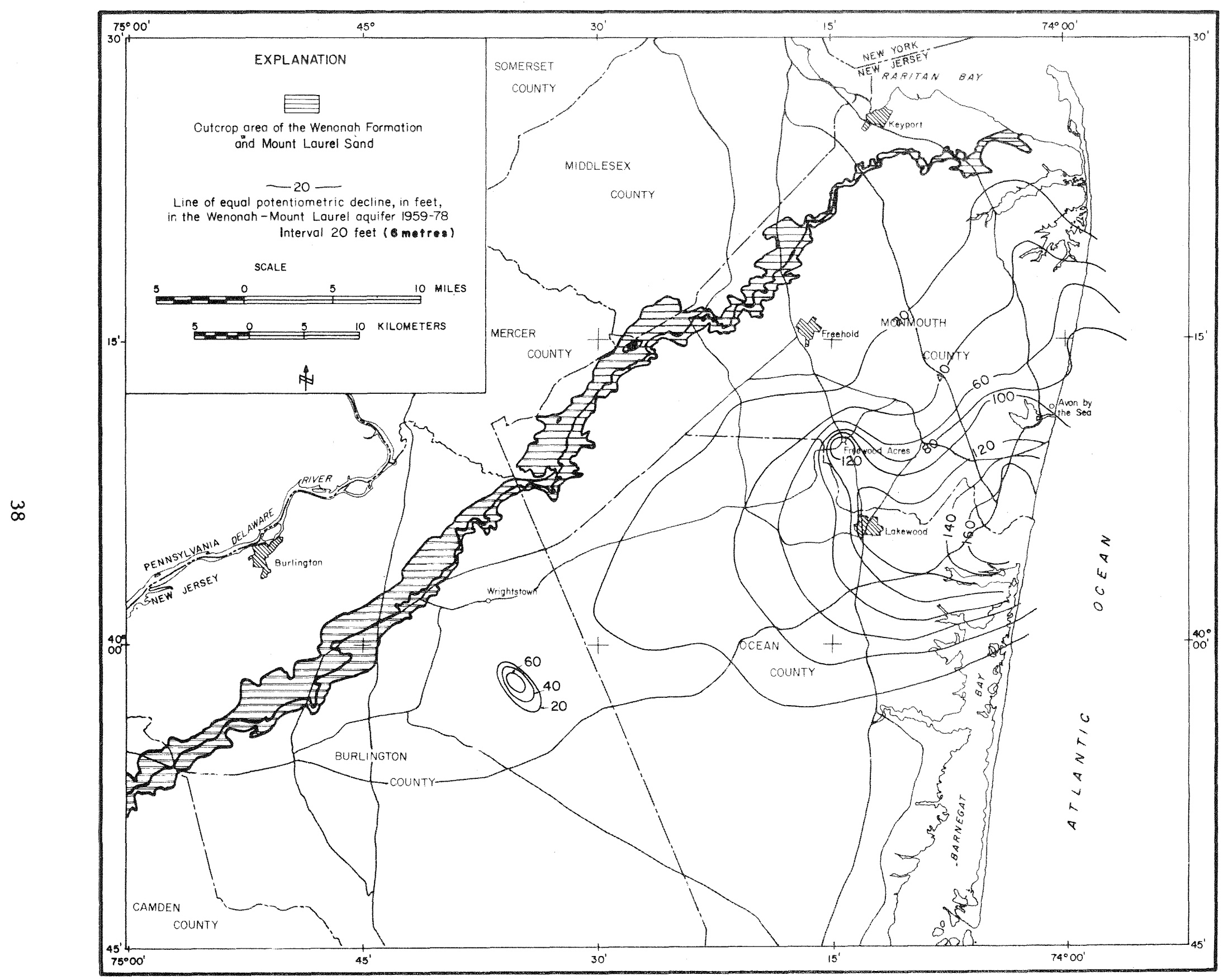

FIGURE 20.PREDICTED POTENTIOMETRIC DECLINE IN THE WENONAH-MOUNT LAUREL AQUIFER BY THE SIMULATION MODEL FOR 1959-78 
drawdown due to pumping in the Wenonah-Mount Laurel aquifer if assumptions are made during the simulation period that the Englishtown aquifer heads will (1) decline at the same rate, (2) stay steady, or (3) decline in a specified fashion. These assumptions presuppose that there is some way to predict Englishtown aquifer heads that does not involve arbitrary assumptions about the Wenonah-Mount Laurel aquifer.

A more accurate representation of the Wenonah-Mount Laurel aquifer would require a multiaquifer model in which the heads, withdrawals, and hydraulic parameters of all the interactive aquifers would be included. This type of model would be more useful for prediction because the true interactive nature of the various parts of the aquifer system could come into play without requiring as many assumptions as are necessary when modelling any single aquifer.

\section{SUMMARY AND CONCLUSIONS}

The simulation model of the Wenonah-Mount Laurel aquifer can be used to evaluate the aquifer's capabilities of meeting projected future demands and to study the cause of the rapidly declining water levels. The modelled area includes $1,500 \mathrm{sq} \mathrm{mi}(3,885 \mathrm{sq} \mathrm{km})$ of the New Jersey Coastal Plain and incorporates all the major centers of pumping in Monmouth, Burlington, and Ocean Counties.

Transmissivity of the aquifer ranges from $4.2 \times 10^{-3} \mathrm{ft}^{2} / \mathrm{sec}(3.9 \mathrm{x}$ $\left.10^{-4} \mathrm{~m}^{2} / \mathrm{sec}\right)$ to $1.5 \times 10^{-2} \mathrm{ft}^{2} / \mathrm{sec}\left(1.5 \times 10^{-3} \mathrm{~m}^{2} / \mathrm{sec}\right)$; the estimated hydraulic conductivity ranges from about $1.5 \times 10^{-4} \mathrm{ft} / \mathrm{sec}\left(4.6 \times 10^{-5}\right.$ $\mathrm{m} / \mathrm{sec})$ to $2.2 \times 10^{-4} \mathrm{ft} / \mathrm{sec}\left(6.7 \times 10^{-5} \mathrm{~m} / \mathrm{sec}\right)$; and the storage coefficient varies from about $1.5 \times 10^{-5}$ to $3.5 \times 10^{-4}$.

The underlying and overlying confining beds, which have an average thickness of $45 \mathrm{ft}(13.7 \mathrm{~m})$ and $200 \mathrm{ft}(61 \mathrm{~m})$, respectively, have hydraulic conductivities which range from $3.0 \times 10^{-9} \mathrm{ft} / \mathrm{sec}\left(9.1 \times 10^{-10} \mathrm{~m} / \mathrm{sec}\right)$ to $2.8 \times 10^{-10} \mathrm{ft} / \mathrm{sec}\left(8.5 \times 10^{-11} \mathrm{~m} / \mathrm{sec}\right)$ for the underlying confining unit and from $2.1 \times 10^{-8} \mathrm{ft} / \mathrm{sec}\left(6.4 \times 10^{-9} \mathrm{~m} / \mathrm{sec}\right)$ to $4.9 \times 10^{-11} \mathrm{ft} / \mathrm{sec}$ $\left(1.5 \times 10^{-11} \mathrm{~m} / \mathrm{sec}\right)$ for the overlying unit. Specific storage ranges from $1.0 \times 10^{-4} \mathrm{ft}^{-1}\left(3.1 \times 10^{-5} \mathrm{~m}^{-1}\right)$ to $3.4 \times 10^{-6} \mathrm{ft}^{-1}\left(1.0 \times 10^{-6} \mathrm{~m}^{-1}\right)$ for the underlying unit and from $3.3 \times 10^{-3} \mathrm{ft}^{-1}\left(1.0 \times 10^{-3} \mathrm{~m}^{-1}\right)$ to $3.1 \times 10^{-6}$ $\mathrm{ft}^{-1}\left(9.4 \times 10^{-7} \mathrm{~m}^{-1}\right)$ for the overlying confining unit.

The annual average rate of withdrawal from the Wenonah-Mount Laurel aquifer in Monmouth, Burlington, and Ocean Counties increased from about $1 \mathrm{Mgal} / \mathrm{d}\left(44 \mathrm{dm}^{3} / \mathrm{sec}\right)$ in 1959 to slightly more than $2 \mathrm{Mgal} / \mathrm{d}\left(88 \mathrm{dm}^{3} / \mathrm{sec}\right)$ in 1970. Near the pumping centers in Monmouth County, the water leve1 declined as much as $100 \mathrm{ft}(30.3 \mathrm{~m})$ between 1959 and 1970 . In the Englishtown aquifer, underlying the lower confining unit (Marshalltown Formation), the annual rate of withdrawal in Monmouth and Ocean Counties increased from $5.5 \mathrm{Mgal} / \mathrm{d}\left(241 \mathrm{dm}^{3} / \mathrm{sec}\right)$ in 1959 to $9.5 \mathrm{Mgal} / \mathrm{d}\left(416 \mathrm{dm}^{3} / \mathrm{sec}\right)$ in 1970. Water-level declines for the same period are as much as $140 \mathrm{ft}$ $(42.7 \mathrm{~m})$ near centers of pumping. Increased withdrawal from the Englishtown 
causes increased leakage from the Wenonah-Mount Laure1 aquifer. The increased leakage from the Wenonah-Mount Laure1, in turn, causes increased declines of Wenonah-Mount Laurel water levels, which then induce additional release of water from the confining beds above. In the same manner, increased withdrawal from the Wenonah-Mount Laurel aquifer affects the rate and magnitude of water-level decline in the Englishtown aquifer. Any decrease in head in the Wenonah-Mount Laurel in response to pumping the same aquifer causes a decrease or even reversal of the head difference between the two aquifers, which, in turn, causes a reduction in the rate and volume of leakage into the Englishtown--leakage which supprrts a large part of the withdrawals from the Englishtown aquifer. As a result, an increase in the rate of water-level decline occurs in the Englishtown aquifer, even with no increase in direct withdrawals.

Because of the importance of leakage into and out of the WenonahMount Laurel aquifer through confining layers, an important feature of the simulation model is the simulation of the head distribution in the aquifers underlying and overlying the confining layers. The Englishtown aquifer water-level declines for the 1959-70 period were incorporated in the model to generate leakage into the Englishtown aquifer, which is the major cause of water-level declines in the Wenonah-Mount Laurel aquifer.

The digital simulation model was calibrated by matching computed declines in the Wenonah-Mount Laurel aquifer with historic water-level declines over the 12-year period, 1959-70. The results of the model analysis show that there is significant recharge to the aquifer from the upper confining unit owing to pumpage. Of equal significance is the effect of water-level declines in the Englishtown aquifer, which generate leakage from the Wenonah-Mount Laurel aquifer through the lower confining unit.

\section{SELECTED REFERENCES}

Anderson, H. R., and Appe1, C. A., 1969, Geology and ground-water resources of Ocean County, N. J.: N, J. Dept. Conserv, and Econ. Deve1. Spec. Rept. 29,93 p., 29 figs.

Barksdale, H. C., Greenman, D. W., Lang, S. M. , Hilton, G. S., and Outlaw, D. E., 1958, Ground-water resources of the tri-state region adjacent to the lower Delaware River: N. J. Dept. Conserv, and Econ. Devel. Spec. Rept. 13, 190 p., 1 plate, 24 figs.

Dames and Moore, 1968, Report ground water supply proposed nuclear generating station near Salem, New Jersey: Public Service Electric and Gas Company, $18 \mathrm{p}$. 
Farlekas, G. M., Nemickas, Bronius, and Gi11, H. E., 1973, Geology and ground-water resources of Camden, N. J.: U. S. Geol. Survey open-file rept.

Hanshaw, B. B., and Bredehoeft, J. D., 1968, On the maintenance of anomalous fluid pressures: II. Source layer at depth: Geol. Soc. America Bu11., v. 79, no. 9, p. 1107-1122.

Hardt, W. F., 1963, Public water supplies in Gloucester County, N. J.: N. J. Dept. Conserv. and Econ. Devel. Water Resources Circ.9.

Hardt, W. F., and Hilton, G. S., 1969, Water resources and geology of Gloucester County, N. J.: N. J. Dept. Conserv, and Econ. Devel, Spec. Rept. 30, 130 p., 17 figs.

Hurr, R. T., 1966, A new approach for estimating transmissibility from specific capacity: Water Resources Research, v. 2, no. 4, p. 657-664.

Jablonski, L. A., 1968, Ground-water resources of Monmouth County, New Jersey: N. J. Dept. Conserv, and Econ. Devel. Spec. Rept. 23, 117 p., 27 figs.

Minard, J. P., 1964, Geology of the Roosevelt Quadrangle, New Jersey: U. S. Geo1. Survey Geol. Quad. Map GQ-340.

1965, Geologic map of the Woodstown Quadrangle, Gloucester and Salem Counties, New Jersey: U. S. Geo1. Survey Geol. Quad. Map GQ-340.

Minard, J. P., Owens, J. P., Soh1, N. F., Gill, H. E., and Mello, J. F., 1969, Cretaceous-Tertiary boundary in New Jersey, Delaware, and eastern Maryland: U. S. Geol. Survey Bu11. 1274-H, 33 p., 10 figs.

Nemickas, Bronius, 1974, Test drilling program to establish observation wells in Cumberland County, New Jersey: U. S. Geol. Survey openfile rept., $34 \mathrm{p}$.

Owens, J. P., and Minard, J. P., 1966, Pre-Quaternary geology of the Allentown Quadrangle, New Jersey: U. S. Geo1. Survey Geo1. Quad. Map GQ -566 .

Owens, J. P., Minard, J. P., and Soh1, N. F., 1968, Cretaceous De1tas in the northern New Jersey Coasta1 Plain, in Finks, R. L., ed., Guidebook to field excursions at the 40th Annual Mtg. of the New York State Geologists Assoc.: New York, Queens College of the City Univ., p. $33-48$.

Owens, J. P., Minard, J. P., Soh1, N. F., and Me11o, J.F., 1970, Stratigraphy of the outcropping post-Magothy Upper Cretaceous formations in southern New Jersey and northern Delmarva Peninsula, Delaware and Maryland: U. S. Geol. Survey Prof. Paper 674, 60 p., 25 figs. 
Owens, J. P., and Soh1, N. F., 1969, Shelf and deltaic paleoenvironments in the Cretaceous-Tertiary formations of the New Jersey Coastal Plain, in Subitzky, Seymour, ed., Geology of selected areas in New Jersey and eastern Pennsylvania and guidebook of excursions: Geol. Soc. America and assoc. soc. annual mtg., Atlantic City, N. J., 1969, p. $235-278$.

Parker, G. G., Hely, A. G., Keighton, W. B., Olmsted, F. H., and others, 1964, Water resources of the Delaware River basin: U. S. Geol. Survey Prof. Paper 381, 200 p., 12 plates, 75 Eigs.

Pinder, G. F., 1970, A digital model for aquifer evaluation: U. S. Geol. Survey, Techniques of Water-Resources Inv, book 7, chap. C1, $18 \mathrm{p}$.

Pinder, G. F., and Bredehoeft, J. D., 1968, Application of the digital computer for aquifer evaluation: Water Resources Research, $v, 4$, no. 5, p. 1069-1093.

Riley, F. S., 1970, Analysis of borehole extensometer data for central California: Tokyo, Japan, Internat. Symposium on Land Subsidence, 1969, Proc.s p. 423-430.

Rooney, J. G., 1971, Ground-water resources Cumberland County, New Jersey; N. J. Dept. Environ. Prot. Spec. Rept. 34, 65 p.

Rosenau, J. C., Lang, S. M., Hilton, G. S., and Rooney, J. G., 1968, Geology and ground-water resources of Salem County, N. J.: N. J. Dept. Conserv, and Econ. Deve1. Spec. Rept. 33, 142 p., 21 figs.

Von Rosenberg, U. D., 1969, Methods for the numerical solution of partial differential equations: New York, Am. Elsevia Publishing Co., Inc., $128 \mathrm{p}$.

Rush, F. E., 1968, Geology and ground-water resources of Burlington County, N. J.: N. J. Dept. Conserv, and Econ. Deve1. Water Resources Circ. 7.

Terzaghi, Karl, 1943, Theoretical soil mechanics: New York, John Wiley and Son, Inc., $510 \mathrm{p}$.

Terzaghi, Kar1, and Peck, R. B., 1967, Soil mechanics in engineering practice [2nd ed.]: New York, John Wiley and Sons, Inc., 729 p.

Trescott, Peter C., 1973, Iterative digital model for aquifer evaluation: U.S. Geol. Survey, open-file report, $63 \mathrm{p}$. 